\title{
Older and Younger Holsteinian climate oscillations in the palaeobotanical record of the Brus profile (SE Poland)
}

\author{
Anna HRYNOWIECKA ${ }^{1, *}$ and Irena A. PIDEK ${ }^{2}$ \\ 1 Polish Geological Institute - National Research Institute, Marine Geology Branch, Kościerska 5, 80-328 Gdańsk, Poland \\ 2 Maria Curie-Skłodowska University in Lublin, Department of Geoecology and Palaeogeography, al. Kraśnicka 2cd, 20-718 \\ Lublin, Poland
}

Hrynowiecka, A., Pidek, I.A., 2017. Older and Younger Holsteinian climate oscillations in the palaeobotanical record of the Brus profile (SE Poland). Geological Quarterly, 61 (4): 723-737, doi: 10.7306/gq.1358

\begin{abstract}
A pollen sequence of Holsteinian/Mazovian age known since the 1980s in Brus (Western Polesie) is the second site with a plant macrofossil record in eastern Poland. High sedimentation rates in a palaeolake that functioned in this area have allowed a detailed climate reconstruction that enabled to trace the Older and Younger Holsteinian oscillations and to outline the water-level changes in the water body. Climate reconstructions, based on full palaeobotanical analyses (pollen and macroremains), were compared with those from Nowiny Żukowskie (Lublin Upland), revealing regional climatic patterns. The two Holsteinian climate oscillations were correlated with those detected in the Dethlingen section of Germany (Koutsodendris et al., 2010), providing more information on the spatial scale of these events.
\end{abstract}

Key words: pollen analysis, macrofossil remains analysis, Mazovian/Holsteinian Interglacial (MIS 11c), palaeoecological and climate reconstruction, E Poland.

\section{INTRODUCTION}

Climate reconstructions of past interglacials are made with different approaches of which palaeobotanical and palaeoecological studies are of main importance as plants are very sensitive to changing environmental conditions. The detailed knowledge of past interglacials, where no human impact was observed, is significant in the context of Holocene climate changes. It is important to distinguish natural and anthropogenic causes of temperature changes, circulation of air masses, maritime influence and other factors for the need of future scenarios of climate changes. Interglacials have been investigated to address the problem of cyclicity, global circulation models, solar forcing, and related subjects (de Beaulieu et al., 2001; Thomas, 2001; Müller et al., 2005; Brauer et al., 2007; Tzedakis et al., 2009; Tzedakis, 2010; Head and Gibbard, 2015 and references therein). Two of the most studied interglacials preceding the Holocene warming have received a particular interest. These are the Eemian Interglacial that is correlated with Marine Isotope Stage $5 \mathrm{e}$ (MIS 5e), and the Holsteinian Interglacial that is correlated with MIS 11c (Lee et al., 2004; Head and Gibbard, 2015). The stratigraphic position of the Holsteinian Interglacial (that is equivalent to the Hoxnian Interglacial in the British Isles,

\footnotetext{
* Corresponding author, e-mail: anna.hrynowiecka@pgi.gov.pl Received: November 4, 2016; accepted: March 16, 2017; first published online: May 5, 2017
}

and the Mazovian Interglacial in Poland) has been much debated in the literature (among others Reille et al., 2000; de Beaulieu et al., 2001; Desprat et al., 2005; Nitychoruk et al., 2005, 2006; Ashton et al., 2008). However, in the latest investigations the Holsteinian is correlated with Marine Isotope Stage 11c (MIS 11c) (Koutsodendris et al., 2010; Head and Gibbard, 2015 and references therein).

Recently, much attention has been paid to the Holsteinian Interglacial because it represents a long-lasting warm period with one distinct intra-interglacial cooling called, after Koutsodendris et al. (2010), Older Holsteinian Oscillation (OHO), and one, less expressed, called Younger Holsteinian Oscillation (YHO). A high-resolution pollen record from Dethlingen (northern Germany) has proved to be very useful for estimation of the duration of both the events due to varved sedimentation. The Holsteinian has recently been under detailed study, as MIS 11c is considered to be one of the closest climate analogue for the Holocene (Ruddiman, 2005; Tzedakis, 2010; Koutsodendris et al., 2011, 2012, 2013).

The Holsteinian Interglacial has been investigated in many palaeobotanical studies. Rich Holsteinian fossil records are known from the lowlands of eastern Poland (Krupiński, 2000; Żarski et al., 2005). About 40 of them have been studied palynologically revealing vegetation dynamics and climate changes (e.g., Brem, 1953; Sobolewska, 1977; Bińka and Nitychoruk, 1995, 1996; Krupiński, 2000; Pidek, 2003; Hrynowiecka-Czmielewska, 2010; Pidek et al., 2011; Hrynowiecka and Winter, 2016). One of them is Brus in Western Polesie (Fig. 1), known since 1980 (Buraczyński and Wojtanowicz, 1982). The pollen and diatom analysis enabled the reconstruction of vege- 


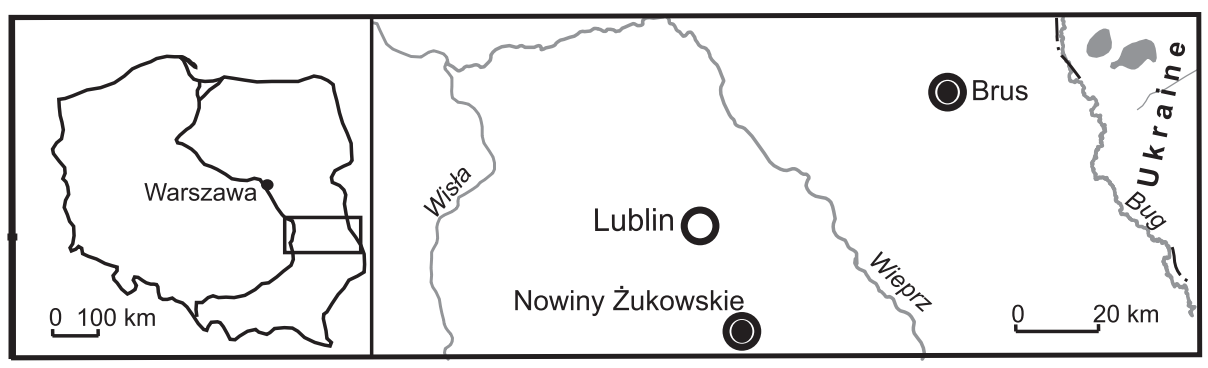

Fig. 1. Location of the Brus and Nowiny Żukowskie sites

tation history and outlined the palaeoclimate changes as well as the evolution of the palaeolake with a high sedimentation rate (Pidek, 2003; Khursevich et al., 2003). A distinct intra-interglacial cooling event is expressed in the Brus pollen diagram by a decrease of Taxus and a simultaneous increase of Pinus pollen percentages. It remains unclear whether this event was caused by climate cooling or dryness, or a combination of both. The same features have been found in the Nowiny Żukowskie profile. Authors compared events from Brus and Nowiny Żukowskie to the $\mathrm{OHO}$ event from Dethlingen (Koutsodendris et al., 2012). Nowiny Żukowskie (Fig. 1) is the first long Holsteinian profile in the Lublin Upland (E Poland) with a complete palaeobotanical record (pollen and macrofossil remains; Hrynowiecka-Czmielewska, 2010). The Brus and Nowiny Żukowskie profiles are situated $\sim 80 \mathrm{~km}$ apart in eastern Poland.

No plant macrofossils have been analysed so far in the Brus profile to find any confirmation of this climate oscillation and rush plant communities in the lake.

The Younger Holsteinian Oscillation is less clear and occurs in the younger part of the interglacial optimum. It is marked by a rapid decline of Carpinus pollen followed by a distinct rise of Abies percentages.

The correlation of both the $\mathrm{OHO}$ and $\mathrm{YHO}$ events from Dethlingen (Koutsodendris et al., 2012, 2013) with pollen and macrofossil data from Nowiny Żukowskie allowed for alignment of warming and cooling trends within the Holsteinian Interglacial, as preliminarily determined in the Nowiny Żukowskie palaeobotanical record, using the climate indicator method (Hrynowiecka and Winter, 2016).

Both oscillations are observable in the pollen diagram from Brus. Because of the high sedimentation rates, the pollen diagram of Brus has a higher resolution than Nowiny Żukowskie, providing more details on the nature of these oscillations in eastern Poland. This fact encouraged the authors to conduct macrofossil analysis of the Brus fossil lacustrine deposits so that it was able to support the record of climate oscillations in more detail by both palaeobotanical methods and subsequently compare it to Nowiny Żukowskie. The aim of the study is to trace similarities and differences between both pollen and macrofossil data from Brus and Nowiny Żukowskie in E Poland. Special attention is paid to the $\mathrm{OHO}$ and $\mathrm{YHO}$ and their comparison with the Dethlingen pollen diagram in northern Germany in terms of tracing the west-east continentality climatic gradient. The study also tries to solve the problem how the plant macroremains data support or reject the existence of the $\mathrm{OHO}$ and $\mathrm{YHO}$ climate events in the Brus profile.

\section{MATERIAL AND METHODS}

\author{
POLLEN ANALYSIS
}

The profile of lacustrine and peat deposits from Brus is $21 \mathrm{~m}$ long (3.80-24.70 m b.g.l.). Palynological analysis was carried out on 106 samples, 18 of which come from the peat. The methods of laboratory treatment of pollen samples were described in Pidek (2003).

The palynological results are presented as a percentage pollen diagram (Fig. 2) that was prepared using the POLPAL software (Nalepka and Walanus, 2003). Pollen succession from Brus was divided into 12 local pollen assemblage zones (L PAZs) numbered from the bottom upwards in the organogenic sequence (Pidek, 2003).

\section{PLANT MACROFOSSILS ANALYSIS}

The methodology was described in detail by Hrynowiecka and Szymczyk (2011) and Stachowicz-Rybka (2011). The macroremains diagram was drawn using the POLPAL software (Nalepka and Walanus, 2003).

A hundred and ten samples were analysed, which were collected from the same depths as the palynological ones. Sixty-six taxa were determined, including 14 trees and shrubs (9 determined to the level of species, section -2 , family -2 , and genus 1), 13 terrestrial plants (all determined to the species level), 15 rush plants ( 13 to the species level and 2 to the type level) and 16 aquatic plants (12 - to the species, 1 - to the family, and 3 - to the genus), and 8 others representing fungi, bryozoans, Cladocerans, leaves, fishes, shells of mollusc and fragments of insects.

The counts were valorized to avoid too much extension of the diagram (for graphic explanations see Fig. 3). Determinations were made i.a. by the use of atlases of plant remains (Velichkevich and Zastawniak, 2006, 2008).

The plant macrofossil succession was divided into 11 macrofossil assemblage zones (Fig. 3). The names of L MAZ were created in such a way that the names of aquatic plants and rushes were given in the first place and the name of terrestrial plants in brackets.

Details about the content of macroremains in each zone are described in Table 1. 


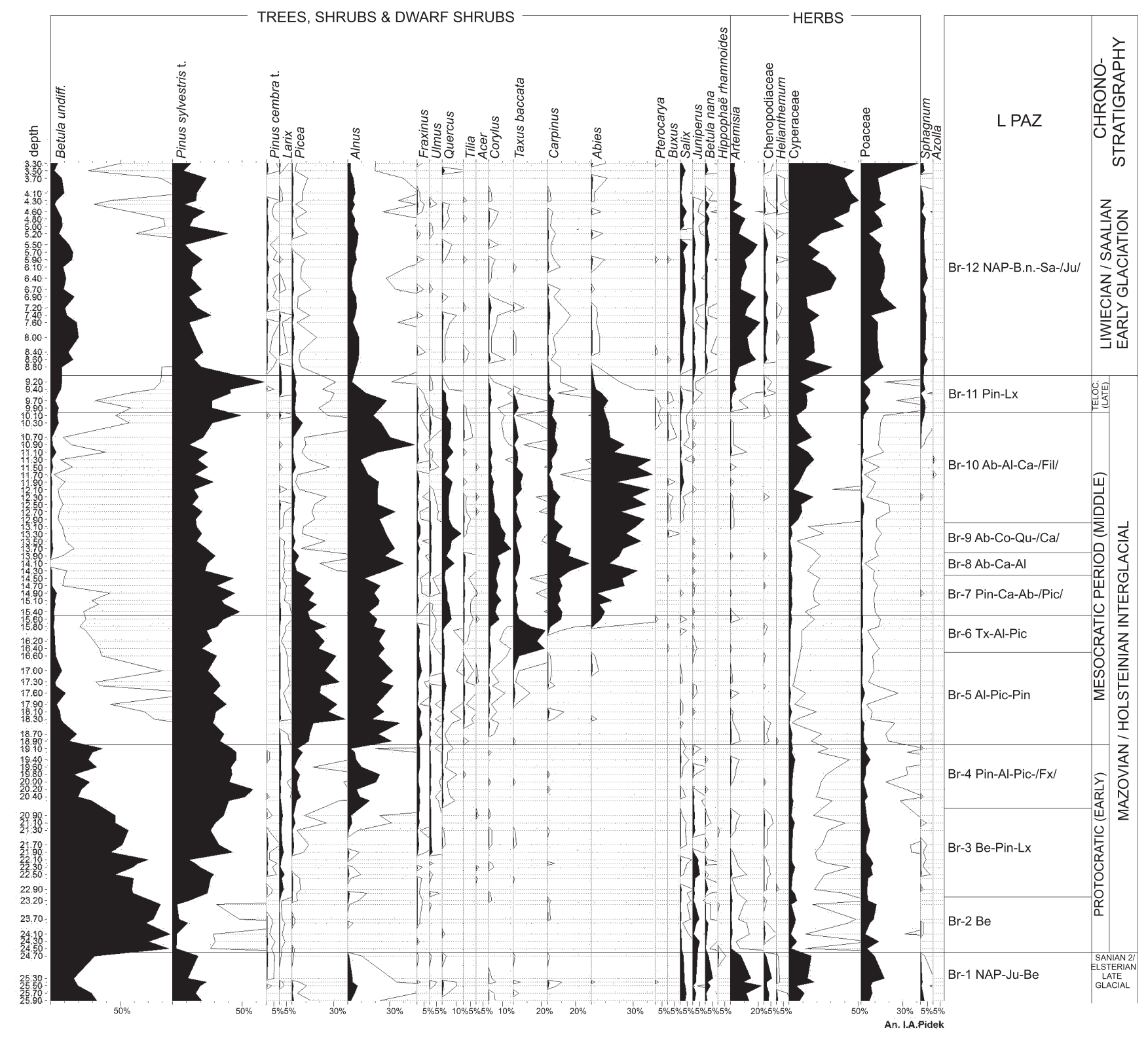

Fig. 2. Simplified pollen diagram from Brus

Teloc. - telocratic phase

\section{RESULTS AND INTERPRETATION OF PALAEOBOTANICAL INVESTIGATIONS}

The vegetation history derived from both plant micro- and macroremains is described in chronological order starting from the pollen spectra representing the Late Gacial of the Sanian 2 $(=$ Elsterian Glaciation = MIS 12) through the whole Mazovian/Holsteinian Interglacial succession, to the Early Glacial of the Liwiecian (=Saalian Glaciation = MIS 10). Within the interglacial, a traditional subdivision is used (protocratic, mesocratic, telocratic periods). The $\mathrm{OHO}$ and $\mathrm{YHO}$ were separately distinguished within the mesocratic period.

Vegetation history recorded in this organogenic sequence starts with open communities of the Late Glacial preceding the interglacial warming, and is reflected in the Br-1 NAP-Juniperus-Betula L PAZ (Fig. 2). Vast areas were covered by steppe-like communities especially in drier habitats. Grasslands with juniper developed on dry poor soils. Extensive areas were covered by various tundra communities, as evidenced by considerable values of Cyperaceae pollen and relatively high frequencies of Betula nana t. and Salix pollen.

Tree birches were probably scattered or formed small patches with admixture of larch and pine. The very high values of redeposited pre-Quaternary sporomorphs indicate intense soil erosion processes that occurred due to a low plant cover. The terrestrial record agrees with that based on plant macrofossils (BR MAZ 1). The zone bears only sporadic fossils of plants (Table 1). The reservoir in Brus started functioning at the end of the Sanian 2 (= Elsterian Glaciation), as a mesotrophic and shallow lake, as evidenced by the presence of Nuphar, probably surrounded by peat bogs (Sphagnum leaves) and rushes with Carex sp. Sclerotia of Cenococcum geophillum confirm the unstable soil cover. The catchment 


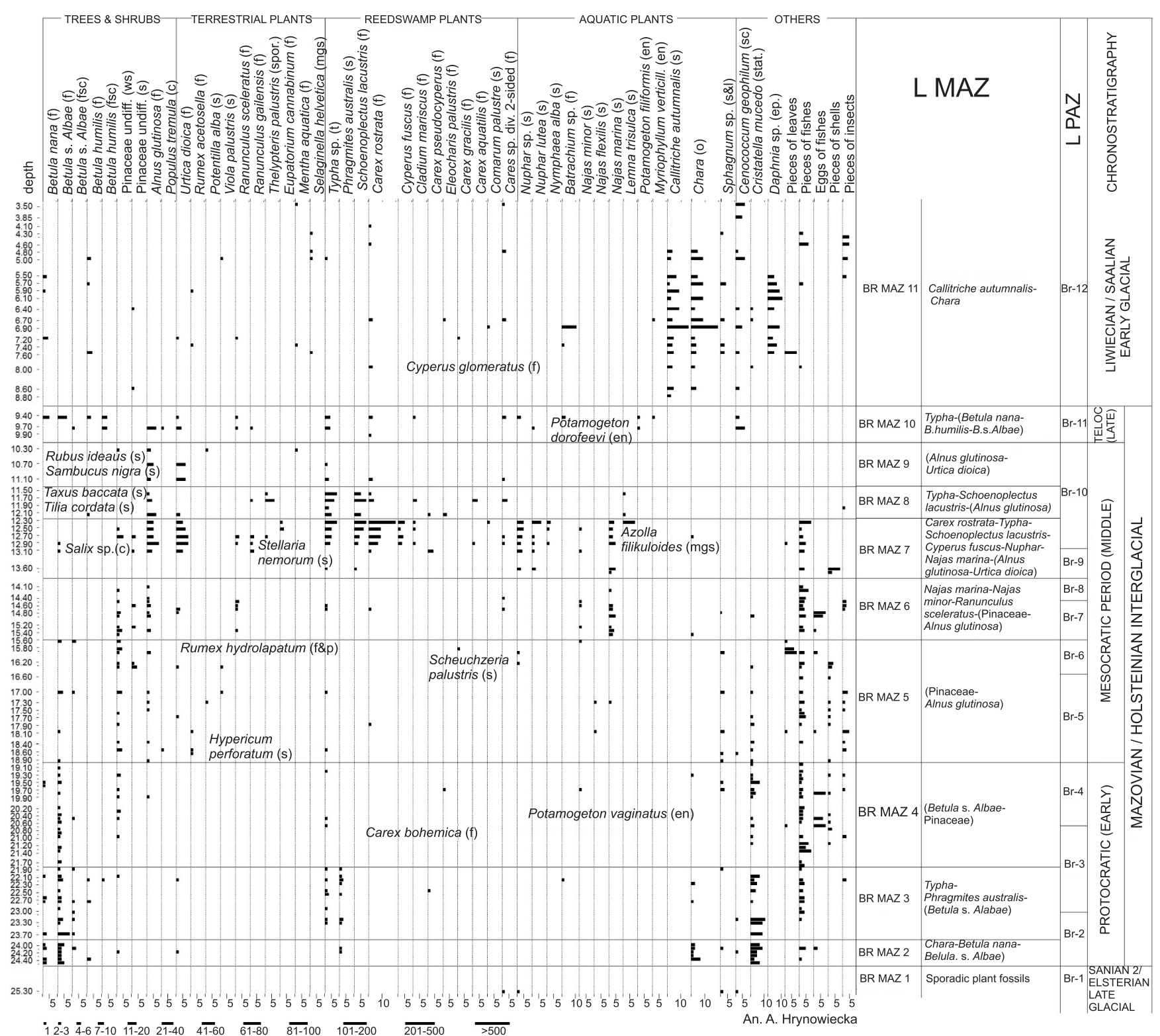

Fig. 3. Simplified macrofossil histogram from Brus

c - capsules, en - endocarps, ep. - ephippium of Daphnia, f - fruit, fsc - fruit scale, f\&p - fruit and perianth, mgs - megaspores, o- oospore, s - seeds, sc - sclerotia, ws - wing of seed, spor. - sporangium, stat. - statoblasts of Bryozoa,

$\mathrm{s} \& \mathrm{l}-\mathrm{stem}$ and leaves of Sphagnum, $\mathrm{t}-$ tegmen

area was probably poorly covered with vegetation (Stachowicz-Rybka, 2011).

Macroscopic remains of Sphagnum can be considered remnants of the initial peat (Tobolski, 2000). Colonies of Pediastrum kawraiskyi indicate low trophy of the lake at that time (Jankovská and Komárek, 2000).

\section{MAZOVIAN INTERGLACIAL}

\section{PROTOCRATIC PHASE}

Br-2 Betula L PAZ. Pioneer birch forest occupied open areas. Alder and ash started to grow on wet habitats. Grass com- munities with abundant juniper and patches of shrub tundra still persisted in many places. The older part of the $\mathrm{Br}-2 \mathrm{~L} P A Z$ correlates with the BR MAZ 2 Chara-(Betula nana-Betula s. Albae). Betula nana and $B$. humilis fruits indicate that the climate was cool (Table 2). In the surroundings of the palaeolake, communities with Betula s. Albae and Pinus sylvestris spread. The edges were covered by a reed belt with Phragmites australis. The reservoir was probably still shallow, which facilitated heating of the water, allowing occurrence of bryozoans Cristatella mucedo that, prefer warm lakes with a water temperature $\sim 11-16^{\circ} \mathrm{C}$ (Økland and Økland, 2000). Moreover, they live in relatively clear water with at least an average content of $\mathrm{CaCO}_{3}$ (Bennike et al., 1994) and $\mathrm{pH}>5.4$ ( $\varnothing \mathrm{kland}$ and $\varnothing \mathrm{kland}, 2000$ ). Such water parameters are confirmed by the occurrence of Chara (Table 2), that is also an indicator of high $\mathrm{CaCO}_{3}$ content and higher $\mathrm{pH}$. The initial 
Description of local macrofossil assemblage zones from the Brus profile (L MAZ)

\begin{tabular}{|c|c|c|c|}
\hline L MAZ & Depth [m] & Name of L MAZ & Description of local macrofossil assemblage zones \\
\hline BR 1 & 25.30 & $\begin{array}{l}\text { Sporadic plant } \\
\text { fossils }\end{array}$ & $\begin{array}{l}\text { The zone is represented by } 1 \text { sample. Sporadic fossil macroremains. Only a fragment of } \\
\text { Nuphar sp. seed, two-sided fruit of Carex, stalk of Sphagnum sp., and sclerotium of } \\
\text { Cenococcum geophilum are determined. } \\
\text { Upper boundary of the zone is marked by the onset of numerous occurrence of Chara, } \\
\text { Betula s. Albae, and Betula nana. }\end{array}$ \\
\hline BR 2 & $24.50-24.0$ & $\begin{array}{c}\text { Chara-(Betula } \\
\text { nana-Betula. s. } \\
\text { Albae) }\end{array}$ & $\begin{array}{l}\text { The zone is represented by } 6 \text { samples. Fruits of Betula s. Albae and B. nana are numerous. } \\
\text { Betula humilis and Pinaceae (wings of seeds) are present. Among humid habitat plants, } \\
\text { fruits of Urtica dioica are found. Swamp plants are represented by seeds of Phragmites aus- } \\
\text { tralis. Aquatic plants comprise numerous oospores of Chara. Numerous are statoblasts of } \\
\text { Cristatella mucedo bryozoan species. Less frequent are stalks of Sphagnum sp., and } \\
\text { sclerotium of Cenococcum geophilum. } \\
\text { Upper boundary of the zone is determined by the disappearance of Chara oospores and ap- } \\
\text { pearance of Typha sp. tegmens. }\end{array}$ \\
\hline BR 3 & $23.70-21.90$ & $\begin{array}{c}\text { Typha-Phragmites } \\
\text { australis-(Betula s. } \\
\text { Albae) }\end{array}$ & $\begin{array}{l}\text { The zone is represented by } 13 \text { samples. Among trees and shrubs, the most numerous are } \\
\text { fruits of Betula s. Albae (maximum of occurrence), less frequent are B. nana, B. humilis, and } \\
\text { Pinaceae. Remains of plants typical of wet and humid habitats are represented by Urtica } \\
\text { dioica. Among swamp plants, Typha sp. and Phragmites australis are very numerous and } \\
\text { accompanied by a single seed of Carex pseudocyperus. Aquatic plants are represented by } \\
\text { fruit of Batrachium sp., oospores of Chara, and stalks of Sphagnum sp. Numerous are also } \\
\text { sclerotia of Cenococcum geophilum and statoblasts of Cristatella mucedo. } \\
\text { Upper boundary of the zone is marked by the disappearance of Phragmites australis seeds } \\
\text { and much less frequent tegmens of Typha sp. }\end{array}$ \\
\hline BR 4 & $21.80-19.0$ & $\begin{array}{c}\text { (Betula s. } \\
\text { Albae-Pinaceae) }\end{array}$ & $\begin{array}{l}\text { The zone is represented by } 24 \text { samples. Quite numerous are remains of Betula s. Albae and } \\
\text { Pinaceae trees. Betula nana and Alnus glutinosa occur sporadically. Among swamp plants, } \\
\text { remains of Typha sp., fruit of Eleocharis palustris, and fruit of Carex bohemica are only pres- } \\
\text { ent. Rare aquatic plant remains are represented by seeds of Caulinia minor, endocarp of } \\
\text { Potamogeton vaginatus, oospore of Chara, and stalk of Sphagnum sp. There are still many } \\
\text { sclerotia of Cenococcum geophilum. Statoblasts of Cristatella mucedo initially disappear } \\
\text { and then occur in higher frequency. } \\
\text { Upper boundary of the zone is marked by less frequent Betula s. Albae fruits and more sys- } \\
\text { tematic appearance of Alnus glutinosa. }\end{array}$ \\
\hline BR 5 & $18.90-15.60$ & $\begin{array}{c}\text { (Pinaceae-Alnus } \\
\text { glutinosa) }\end{array}$ & $\begin{array}{l}\text { The zone is represented by } 17 \text { samples. Among tree remains, the most numerous are } \\
\text { Pinaceae and Alnus glutinosa. Much scarce are remains of Betula s. Albae. Capsules of } \\
\text { Populus tremula appears. There is high variability among the remains of plants growing at } \\
\text { the reservoir's edge, including: Urtica dioica, fruit of Rumex acetosella, R. hydrolapatum, } \\
\text { Ranunculus sceleratus, and seeds of Potentilla alba, Viola palustris and Hypericum } \\
\text { perforatum. However, swamp plant remains are poorly represented, including single } \\
\text { macrofossils of Typha sp., Carex rostrata, C. gracilis and Scheuchzeria palustris. Among } \\
\text { aquatic plants, Sphagnum sp. branches are common. Nuphar sp., Najas minor and N. } \\
\text { flexilis are also found. Statoblasts of Cristatella mucedo occur less frequently. } \\
\text { Upper boundary of the zone is drawn below the abundant appearance of Najas marina } \\
\text { seeds. }\end{array}$ \\
\hline BR 6 & $15.40-14.10$ & $\begin{array}{l}\text { Najas marina-Najas } \\
\text { minor-Ranunculus } \\
\text { sceleratus- } \\
\text { (Pinaceae-Alnus } \\
\quad \text { glutinosa) }\end{array}$ & $\begin{array}{l}\text { The zone is represented by } 11 \text { samples. There are still numerous seeds of Alnus glutinosa } \\
\text { and Pinaceae. Among wet plants, fruits of Urtica dioica and slightly more numerous } \\
\text { Ranunculus sceleratus are preserved. Swamp plant remains are still sporadic and repre- } \\
\text { sented only by Typha sp., Carex rostrata and two-sided Carex. Among aquatic plants, quite } \\
\text { numerous are seeds of Najas marina, } N \text {. minor, and oospores of Chara and Sphagnum sp. } \\
\text { Single statoblasts of Cristatella mucedo appear. } \\
\text { Upper boundary of the zone is marked by constant occurrence of Nupharsp. and Nupharlutea. }\end{array}$ \\
\hline BR 7 & $13.70-12.30$ & $\begin{array}{l}\text { Carex rostrata-Typha } \\
\text {-Schoenoplectus } \\
\text { lacustris-Cyperus } \\
\text { fuscus-Nuphar-Najas } \\
\text { marina-(Alnus } \\
\text { glutinosa-Urtica } \\
\quad \text { dioica) }\end{array}$ & $\begin{array}{l}\text { The zone is represented by } 7 \text { samples. Of tree remains, Alnus glutinosa and Pinaceae ap- } \\
\text { pear most often. Remains of Betula s. Albae is definitely less frequent. Capsules of Salix sp. } \\
\text { is present. Wet and humid habitat plants are numerous and represented by Urtica dioica, } \\
\text { quite often Ranunculus sceleratus, R. gailensis and fruits of Eupatorium cannabinum. } \\
\text { Sporangia of Thelypteris palustris and seeds of Stellaria nemorum are found. Swamp plant } \\
\text { remains are very abundant and represented by Carex rostrata, Typha sp., Schoenoplectus } \\
\text { lacustris and Cyperus fuscus. Less frequent are Cladium mariscus, Carex pseudocyperus, } \\
C \text {. aquatilis and seeds of Comarum palustre. Among aquatic plants, numerous are remains } \\
\text { of Nuphar sp., N. luteum and Najas marina. In the upper part of the zone seeds of Lemna } \\
\text { trisulca often occur. Above, Nymphaea alba, Najas minor, Azolla filikuloides and Chara ap- } \\
\text { pear. } \\
\text { Upper boundary of the zone is determined by a much smaller amount of most taxa. }\end{array}$ \\
\hline BR 8 & $12.10-11.50$ & $\begin{array}{l}\text { Typha-Schoeno- } \\
\text { plectus lacustris- } \\
\text { (Alnus glutinosa) }\end{array}$ & $\begin{array}{l}\text { The zone is represented by } 4 \text { samples. Among trees, Alnus glutinosa is still quite numerous. } \\
\text { Taxus baccata and Tilia cordata appear. Urtica dioica and Ranunculus gailensis are spo- } \\
\text { radic, slightly more frequent are sporangia of Thelypteris palustris. Swamp plant remains } \\
\text { are still represented by numerous Typha sp. and Schoenoplectus lacustris. Less frequent } \\
\text { are Carex rostrata, C. pseudocyperus, C. aquatilis, Cladium mariscus, and Eleocharis } \\
\text { palustris. Aquatic plant remains are scarce and represented only by Lemna trisulca. } \\
\text { Upper boundary of the zone is marked by the disappearance of many taxa. }\end{array}$ \\
\hline BR 9 & $11.10-10.30$ & $\begin{array}{c}\text { (Alnus glutinosa - } \\
\text { Urtica dioica) }\end{array}$ & $\begin{array}{l}\text { The zone is represented by } 3 \text { samples. Among tree remains, only fruits of Alnus glutinosa } \\
\text { occur systematically. Remains of Pinaceae, Rubus ideaus and Sambucus nigra are pres- } \\
\text { ent. Terrestrial plants are represented only by still numerous Urtica dioica and Potentilla } \\
\text { alba, and fruits of Mantha aquatica. A only few remains of swamp plants (Typha sp., Carex } \\
\text { rostrata) are present. Aquatic plants are absent. } \\
\text { Upper boundary of the zone is marked by the frequent occurrence of Typha sp. }\end{array}$ \\
\hline
\end{tabular}




\begin{tabular}{|c|c|c|c|}
\hline L MAZ & Depth $[\mathrm{m}]$ & Name of $L M A Z$ & Description of local macrofossil assemblage zones \\
\hline BR 10 & $9.90-9.40$ & $\begin{array}{c}\text { Typha-(Betula nana } \\
-B . \text { humilis-B. S. } \\
\text { Albae) }\end{array}$ & $\begin{array}{l}\text { The zone is represented by } 3 \text { samples. Quite numerous remains of Betula s. Albae, B. nana } \\
\text { and B. humilis appear again. In addition, Alnus glutinosa and Populus tremula are present. } \\
\text { Wet habitat plants are still represented by Urtica dioica, Ranunculus sceleratus and R. } \\
\text { gailensis. In swamp habitats, numerous are Typha sp. and Carex rostrata; Cladium } \\
\text { mariscus also appears. Aquatic palnts are represented only by single remains of Nuphar } \\
\text { sp.. N. Iuteum, Batrachium sp., Potamogeton dorofeevi, P. filiformis and Myriophyllum } \\
\text { verticillatum. Fairly numerous sclerotia of Cenococcum geophilum also appear. } \\
\text { Upper boundary of the zone is determined by the presence of numerous Chara and } \\
\text { Callitriche autumnalis. }\end{array}$ \\
\hline BR 11 & $8.80-3.50$ & $\begin{array}{c}\text { Callitriche } \\
\text { autumnalis-Chara }\end{array}$ & $\begin{array}{l}\text { The zone is represented by } 21 \text { samples. Macroremains of Betula nana, B. humilis and } \\
\text { Pinaceae undiff. are sparse. Terrestrial plants are represented by single remains of Urtica } \\
\text { dioica, Rumex acetosella, Ranunculus sceleratus and Mentha aquatica. Megaspores of } \\
\text { Selaginella helvetica are present. Among swamp plants, Carex rostrata is more frequent. } \\
\text { Typha sp., Eleocharis palustris, Carex gracilis, Comarum palustre and Cyperus glomeratus } \\
\text { occasionally appear. Aquatic plants are represented by very numerous seeds of Callitriche } \\
\text { autumnalis, oospores of Chara, and relatively frequent fruits of Batrachium sp. Stalks of } \\
\text { Sphagnum sp. are also frequent. Numerous are sclerotia of Cenococcum geophilum. Single } \\
\text { statoblasts of Cristatella mucedo appear. }\end{array}$ \\
\hline
\end{tabular}

bogs developed (Sphagnum leaves). Numerous were sclerotia of Cenococcum geophilum - an ectomycorrhizal fungus, which is common also nowadays and proves intense solifluction processes (Krauss et al., 1965; Fernandez et al., 2013).

In the older part of the zone, diatoms appear. At the beginning of the Mazovian/Holsteinian Interglacial, the water level was still low, which facilitated the heating of water and the development of numerous diatom species (their number increased from 72 to 187; Khursevich et al., 2003). Epiphytic cold-water species initially dominated, like Fragilaria lapponica. Then, many ecological groups of diatoms developed, but mostly preferring cold waters. Among them, the most numerous were planktonic species, e.g. Cyclotella krammeri and $C$. schumannii that point to a water-level rise (Table 2). This is confirmed by numerous oospores of Chara in this part of the profile, which in turn indicate the oligo- to mesotrophy of water conditions (Fig. 3; BR MAZ 2).

Br-3 Betula-Pinus-Larix L PAZ. The increasing proportion of pine in forests at that time is reflected by high values of Pinus sylvestris t. pollen. These birch-pine forests were of boreal type. Larch was a relatively common component of the forests. Grass communities with abundant juniper shrubs and patches of tundra communities with Betula nana and willow shrubs still persisted in the landscape. The proportion of spruce in the forests increased. Alder woods developed on wetter places probably with ash admixture. Ash and elm were also present in wet deciduous forests. The herbaceous vegetation of these communities is reflected by the pollen of, among others, Urtica and Filipendula, and the creeper Humulus lupulus.

The younger part of $\mathrm{Br}-2 \mathrm{~L} P A Z$ and the older part of Br-3 L PAZ correspond with BR MAZ 3 Typha-Phragmites australis-(Betula s. Albae). The catchment of the lake was still covered with tree-birches and pine forest. Typha occurred in the reed belt, which indicates an average July temperature not lower than $13^{\circ} \mathrm{C}$ in the case of $T$. latifolia (Isarin and Bohncke, 1999) and $14^{\circ} \mathrm{C}$ in the case of $T$. angustifolia (Iversen, 1954; Kolstrup, 1979, 1980). It probably formed a belt of rushes with Phragmites australis. At the same time, Betula nana and $B$. humilis persisted on the peat bogs surrounding the lake, which, in combination with the occurrence of Sphagnum leaves, indicates the formation of bogs. Cristatella mucedo still occurred in significant quantities, which, in the absence of other indicators, suggests relatively constant parameters in the lake (temperature, content of $\mathrm{CaCO}_{3}$, and $\mathrm{pH}$ ). The end of this zone and the older part of the BR MAZ 4 was probably marked by a water-level rise in the reservoir.
In the younger part of the protacratic period the reservoir continued to shallow, and a wide belt of rushes with Phragmites australis and Typha latifolia (Fig. 3; BR MAZ 3) allowed for intensified development of epiphytic diatom species, like Fragilaria construens and F. brevistriata. However, planktonic species, like $C$. schumannii, also continued to occur numerously in the lake. In connection with the shallowing, the trophic levels may have grown. Then, a sudden decrease in the amount of diatoms in the younger part of the BR 3 diatom zone (Table 2) indicates unfavourable conditions for their development in the lake - a decrease in water level (Khursevich et al., 2003).

Br-4 Pinus-Alnus-Picea-IFraxinus/ L PAZ. Increasing values of Picea pollen indicate that the importance of this tree in the forests became greater. Quercus may have entered not only riverine communities of ash and elm, but also appeared on more fertile habitats in the pine forests. Corylus probably occurred in the margins of these forests. In the expanding alder forests, ash and spruce may have occurred as an admixture. Ash-elm riverine forests spread in new areas, as is evidenced by the rising pollen values of Fraxinus (max. $2.2 \%$ ), and by the continuous curve of Ulmus. Celtis appeared as well. Taking into account that both UImus and Fraxinus are the low pollen productivity trees (Pidek, 2013), such a proportion of their pollen points to a great role of ash-elm riverine communities.

Relatively high pollen frequencies of Salix and Juniperus, and the sporadic occurrence of Betula nana t. pollen grains indicate that diverse open communities still existed. However, their role in the landscape was less important.

The younger part of $\mathrm{Br}-3 \mathrm{~L}$ PAZ and Br-4 L PAZ corresponds to BR MAZ 4 (Betula s. Albae-Pinaceae). Among the communities growing on the lake shores, birch and pine forests dominated the catchment. In the older part of the zone the water level was drastically reduced, as indicated by the disappearance of rushes and Sphagnum, and by a marked reduction in the occurrence of Cristacella mucedo, which further suggests changes of water conditions and an average July temperature $>10^{\circ} \mathrm{C}$ (Birks, 2000; Eide et al., 2006). In the younger part of the zone, the conditions probably stabilized due to a water-level increase. The amounts of C. mucedo statoblasts increased and Chara appeared again. The truncheons (Typha latifolia) and reed rushes disappeared, which confirms a higher water level. The palaeobasin was very shallow. The littoral silty zone allowed for the development of swampy vegetation with Eleocharis palustris and Carex bohemica (Stachowicz-Rybka, 2011).

The final phase of the protocratic period, correlated with BR 4 L PAZ, was characterized by the numerous and variable occur- 
Summary of L PAZ (Pidek, 2003), L DAZ (Khursevich et al., 2003) and L MAZ showing water level, trophy and $\mathrm{pH}$ changes at the Brus site

\begin{tabular}{|c|c|c|c|c|c|c|c|c|c|c|c|c|c|}
\hline \multirow{2}{*}{\multicolumn{2}{|c|}{$\begin{array}{l}\text { Chrono- } \\
\text { stratigra- } \\
\text { phy }\end{array}$}} & \multirow[t]{2}{*}{$\mathrm{Br} L \mathrm{PAZ}$} & \multirow{2}{*}{$\begin{array}{l}\text { BR } \\
\text { LAZ }\end{array}$} & \multirow{2}{*}{$\begin{array}{c}\text { Tro- } \\
\text { phy } \\
\text { based } \\
\text { on Br } \\
\text { L DAZ }\end{array}$} & \multirow{2}{*}{$\begin{array}{l}\text { Water } \\
\text { level } \\
\text { based } \\
\text { on Br } \\
\text { L DAZ }\end{array}$} & \multirow{2}{*}{$\begin{array}{l}\text { BR L } \\
\text { MAZ }\end{array}$} & \multirow{2}{*}{$\begin{array}{l}\text { Trophy } \\
\text { based on } \\
\text { Br L MAZ }\end{array}$} & \multirow{2}{*}{$\begin{array}{c}\mathrm{pH} \\
\text { based on } \\
\mathrm{Br} L \mathrm{MAZ}\end{array}$} & \multirow{2}{*}{$\begin{array}{c}\text { Water } \\
\text { level } \\
\text { based } \\
\text { on Br L } \\
\text { MAZ }\end{array}$} & \multicolumn{2}{|c|}{$\begin{array}{l}\text { Temperature based on } \\
\text { plant climate indicators } \\
\qquad\left[{ }^{\circ} \mathrm{C}\right]\end{array}$} & \multirow{2}{*}{$\begin{array}{l}\text { Annual } \\
\text { preci- } \\
\text { pitation }\end{array}$} & \multirow{2}{*}{$\begin{array}{l}\text { Climate } \\
\text { based on Br } \\
\text { L PAZ and } \\
\text { Br L MAZ }\end{array}$} \\
\hline & & & & & & & & & & $\begin{array}{c}\text { Mean } \\
\text { of January }\end{array}$ & $\begin{array}{l}\text { Mean } \\
\text { of July }\end{array}$ & & \\
\hline \multicolumn{2}{|c|}{$\begin{array}{l}\text { E. } \\
\text { Liwiecian/ } \\
\text { Saalian Gl. }\end{array}$} & $\begin{array}{l}\text { Br-12 } \\
\text { NAP-B.n. } \\
\text {-Sa-(Ju) }\end{array}$ & \multicolumn{3}{|c|}{ diatoms absent } & BR 11 & Meso- & $>5.4$ & $\uparrow$ & $\begin{array}{c}-12-(-7) \\
0 \text { (max) }\end{array}$ & $8-13$ & Low & $\begin{array}{c}\text { subarctic } \\
\text { continental }\end{array}$ \\
\hline \multirow{9}{*}{ 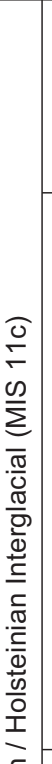 } & 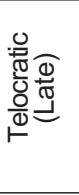 & $\begin{array}{l}\text { Br-11 } \\
\text { Pin-Lx }\end{array}$ & \multicolumn{3}{|c|}{ diatoms absent } & BR 10 & Meso- & $>7$ & $\begin{array}{l}\text { slight } \\
\text { in- } \\
\text { crease }\end{array}$ & $\begin{array}{c}-12 \\
-5-(-4) \\
-3-(-1)\end{array}$ & $\begin{array}{l}10-17 \\
(10) \\
14-15 \\
15-17\end{array}$ & $\begin{array}{l}\text { Low } \\
\downarrow \text { Low }\end{array}$ & $\begin{array}{c}\text { Warm tem- } \\
\text { perate to } \\
\text { cool temper- } \\
\text { ate } \\
\text { Gradual } \\
\text { cooling }\end{array}$ \\
\hline & \multirow{8}{*}{ 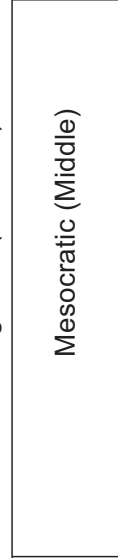 } & \multirow{3}{*}{$\begin{array}{l}\mathrm{Br}-10 \\
\mathrm{Ab}-\mathrm{Al}-\mathrm{Ca} \\
-(\mathrm{Fil})\end{array}$} & \multirow{2}{*}{\multicolumn{3}{|c|}{ diatoms sporadic }} & BR 9 & $\begin{array}{l}\text { Meso- to } \\
\text { Eu- }\end{array}$ & $?$ & further $\downarrow$ & & & & $\begin{array}{c}\text { Warm } \\
\text { temperate }\end{array}$ \\
\hline & & & & & & BR 8 & $\begin{array}{l}\text { Meso- to } \\
\text { Eu- }\end{array}$ & $?$ & shallow & & & & $\mathrm{YHO}$ \\
\hline & & & BR 10 & Eu- & $\downarrow$ Low & & & & & $(-8) 0-3$ & $21-26$ & High & Warm \\
\hline & & $\begin{array}{c}\mathrm{Br}-9 \\
\mathrm{Ab}-\mathrm{Co}-\mathrm{Q} \\
\mathrm{u}-(\mathrm{Ca})\end{array}$ & BR 9 & Eu- & $\begin{array}{c}\uparrow \downarrow \\
\text { unsta- } \\
\text { ble }\end{array}$ & BR 7 & $\begin{array}{l}\text { Eu- } \\
\text { Dys- }\end{array}$ & $\downarrow$ & $\downarrow$ & & & & $\begin{array}{l}\text { temperate } \\
\text { Climate } \\
\text { optimum. }\end{array}$ \\
\hline & & $\begin{array}{c}\mathrm{Br}-8 \\
\mathrm{Ab}-\mathrm{Ca}-\mathrm{Al}\end{array}$ & BR 8 & Eu- & $\begin{array}{l}\text { shal- } \\
\text { low }\end{array}$ & & & & & $(-8)-4(-2)$ & $16-20$ & 个High & Marine \\
\hline & & $\begin{array}{c}\mathrm{Br}-7 \\
\mathrm{Pin}-\mathrm{Ca}- \\
-\mathrm{Ab}-(\mathrm{Pic}) \\
\end{array}$ & BR 7 & Eu- & $\downarrow$ & BR 6 & Eu- & $<7$ & $\downarrow$ & -3 & $12-13$ & $\downarrow$ Low & $\mathrm{OHO}$ \\
\hline & & $\begin{array}{c}\mathrm{Br}-6 \\
\text { Tx-Al-Pic }\end{array}$ & BR 6 & Eu- & high & RP 5 & Meso- to & $>5,1$ & high & $(-5)-(-3)$ & $16-20$ & High & Warm \\
\hline & & $\begin{aligned} & \mathrm{Br}-5 \\
& \text { Al-Pic-Pin } \\
&\end{aligned}$ & BR 5 & Eu- & $\begin{array}{l}\text { } \text { un- } \\
\text { stable }\end{array}$ & DN 0 & Eu- & $>0.4 \downarrow$ & IIIgII & -3 & 17.7-18 & High & temperate \\
\hline 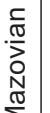 & $\widehat{X}$ & $\begin{array}{c}\mathrm{Br}-4 \\
\mathrm{Pin}-\mathrm{Al}- \\
-\mathrm{Pic}-(\mathrm{Fx}) \\
\end{array}$ & BR 4 & $\begin{array}{l}\text { Meso- } \\
\text { to Eu- }\end{array}$ & Low & BR 4 & $\begin{array}{l}\text { Meso- to } \\
\text { Eu- }\end{array}$ & $>5.4$ & $\begin{array}{c}\text { } \text { unsta- } \\
\text { ble }\end{array}$ & -1.5 & $15-21$ & $\uparrow$ & $\begin{array}{l}\text { Cool } \\
\text { temperate to } \\
\text { warm } \\
\text { temperate }\end{array}$ \\
\hline 2 & $\underset{.}{\stackrel{0}{\tilde{U}}}$ & $\begin{array}{c}\text { Br-3 } \\
\text { Be-Pin-Lx }\end{array}$ & BR 3 & Meso- & $\begin{array}{l}\text { shal- } \\
\text { low }\end{array}$ & & & & & & & & Cool \\
\hline & $\begin{array}{l}\frac{\pi}{0} \\
\frac{0}{0} \\
\frac{0}{0} \\
0\end{array}$ & & BR 2 & Oligo- & $\uparrow$ & BR 3 & $\begin{array}{l}\text { Meso- to } \\
\text { Eu- }\end{array}$ & $>5.4$ & shallow & $\begin{array}{c}-1.5-0 \\
(\max )\end{array}$ & $12-14$ & Low & $\begin{array}{c}\text { temperate. } \\
\text { Boreal. } \\
\text { Warmer }\end{array}$ \\
\hline & & & BR 1 & Oligo- & $\begin{array}{l}\text { shal- } \\
\text { low }\end{array}$ & BR 2 & $\begin{array}{l}\text { Oligo- to } \\
\text { Meso- }\end{array}$ & $>5.4$ & shallow & & & & $\begin{array}{c}\text { Cool } \\
\text { temperate. } \\
\text { Boreal }\end{array}$ \\
\hline $\begin{array}{l}\mathrm{L} \\
\mathrm{Sa} \\
\text { Els }\end{array}$ & $\begin{array}{l}\text { ate } \\
\text { ian2/ } \\
\text { erian } \\
\text { Sl. }\end{array}$ & $\begin{array}{c}\text { Br-1 } \\
\text { NAP-Ju- } \\
\text {-Be }\end{array}$ & & toms ab & sent & BR 1 & $\begin{array}{l}\text { Oligo- to } \\
\text { Meso- }\end{array}$ & $?$ & shallow & $0(\max )$ & $8-13$ & Low & $\begin{array}{l}\text { Subarctic. } \\
\text { Continental }\end{array}$ \\
\hline
\end{tabular}

Summary of Mazovian/Holsteinian Interglacial temperature (the lowest mean and highest mean of January and July), annual sum of precipitation, and climatic conclusions in comparison to the L PAZ and L MAZ from the Brus site are also given. Sum of precipitation: High - >1000 mm, Low $<500 \mathrm{~mm}$. Explanations to symbols: $\uparrow$ - increase, $\downarrow$ - decrease. Oligo - Oligotrophic, Meso - Mesotrophic, Eu - Eutrophic, Dys - Dystrophic; L PAZ - Local Pollen Assemblage Zones, L DAZ - Local Diatom Assemblage Zones, L MAZ - Local Macroremains Assemblage Zones

rence of diatoms (mainly from the genera Cyclotella, Fragilaria and Amphora) and Pediastrum that indicate meso- to eutrophic conditions, but also unstable water conditions (Khursevich et al., 2003; Table 2). On the other hand, the development of Alnus upon wet habitats at that time might have changed the groundwater level and trophic conditions, which supports the notion for instable water conditions as inferred by the diatoms. The maximum number of diatoms (at depths of $20.5 \mathrm{~m}$ and 19.5-19.9 m) seems to correspond with two distinct maxima of alder in the pollen diagram (Khursevich et al., 2003; Fig. 2).

\section{MESOCRATIC PHASE}

Br-5 Alnus-Picea-Pinus L PAZ. The mesocratic phase of the interglacial is marked by a distinct transformation of forest communities reflected in the $\mathrm{Br}-5$ and $\mathrm{Br}-6 \mathrm{~L} \mathrm{PAZs}$. Boreal pine-birch forests transformed into mixed forests, in which birch almost disappeared, the proportion of pine decreased, and spruce became dominant. Quercus probably occurred as an admixture in these communities. Alder forests, ash-elm and alder-ash riverine forests occupied more and more exten- 
sive areas throughout this zone. The composition of the riverine communities became even richer in the younger part of the zone, with lime playing an important role.

Br-6 Taxus-Alnus-Picea L PAZ. Rapid rise of Taxus pollen values provides evidence of the dominant role of yew in forest communities. From wet alder forests, yew could have expanded to other forest communities. Dry-ground communities with Carpinus, Quercus and Corylus started to develop. The tree layer was probably composed of hornbeam and oak with an admixture of lime, spruce and single fir trees. Hazel spread in margins and clearings of fertile dry-ground forests.

The $\mathrm{Br}-5$ and $\mathrm{Br}-6 \mathrm{~L}$ PAZs correspond to BR MAZ 5 (Pinaceae-Alnus glutinosa). In the older part of the zone, the reservoir was characterized mostly by meso- to eutrophic conditions, as inferred by the presence of Najas flexilis that optimally occurs in mesotrophic waters. Numerous statoblasts of Cristatella mucedo indicate a constant $\mathrm{CaCO}_{3}$ content and $\mathrm{pH}$ $>5.4$ ( Økland and Økland, 2000). In the younger part of the zone, the trophic state increased, as evidenced by the appearance of Najas marina and Nuphar, and thermophilic Najas minor that optimally occurs in strongly eutrophic waters (Thiébaut, 2008; Stachowicz-Rybka, 2011). However, the reservoir should be classified as meso/eutrophic. Simultaneously, the decrease in water $\mathrm{pH}$ should eliminate $C$. mucedo. The reason for the decrease in $\mathrm{pH}$ was a mosaic of bogs, including the ones with Scheuchzeria palustris. The decrease in $\mathrm{pH}$ can also be caused by the neighbourhood of alder bog with Alnus glutinosa, Urtica dioica and Viola palustris and patches of transitional mires. In a shallow littoral zone, rushes with Typha sp. and sedge communities with Carex rostrata and C. gracilis appeared. Rumex acetosella and Potentilla alba indicate the vicinity of dry, open communities (Stachowicz-Rybka, 2011).

At the beginning of the mesocratic period the water of the lake was warm and eutrophic, which is confirmed by diatom species, like Aulacoseira granulata, A. ambigua and Stephanodiscus niagarae var. insuetus (Khursevich et al., 2003). However, diversity of diatom species was greater. Planktonic species, like Cyclotella krammeri, C. cyclopuncta and extinct $C$. comta var. lichvinensis (the indicator of the Mazovian/Holsteinian Interglacial; Khursevich et al., 2003) were numerous and confirm the rise in water level (Table 2). Eutrophisation and high water temperature is also suggested by the abundant presence of Chlorophyta, such as Pediastrum boryanum var. boryanum, $P$. boryanum var. cornutum, $P$. boryanum var. pseudoglabrum and $P$. duplex var. rugulosum (Pidek, 2003).

\section{OLDER HOLSTEINIAN OSCILLATION (OHO)} WITHIN THE MSOCRATIC PHASE

Br-7 Pinus-Carpinus-Abies-IPiceal L PAZ. A sudden decrease in Taxus pollen values followed by a considerable rise in Pinus sylvestris t. values (up to $42 \%$ ), and a fall in the percentages of Picea, Alnus, Fraxinus and Ulmus indicate a considerable reduction of yew stands and areas covered by wet forests. This was probably caused by a climate change towards much more continental and perhaps also colder conditions during the $\mathrm{OHO}$. The onset of this oscillation is marked by a reduction in temperate trees and expansion of pine. According to the varve chronology of the Dethlingen core (Koutsodendris et al., 2011, 2012) this period lasted $\sim 90$ years.

Subsequently, pollen values of Quercus increased simultaneously with the Carpinus and Corylus values, providing evidence of the development of mixed pine-oak forests and the expansion of fertile dry-ground hornbeam-oak forests with hazel. These communities may be correlated with the recovery phase in the second part of the $\mathrm{OHO}$, which lasted $\sim 130$ years in Dethlingen (Koutsodendris et al., 2011, 2012). Lime, spruce and fir might have occurred as an admixture in these communities.

A dynamic expansion of Abies started in the younger part of the $\mathrm{Br}-7 \mathrm{~L}$ PAZ, in which its pollen values reached $19-20 \%$. At that time, Abies could have formed fir forests probably with a spruce admixture. The very rapid increase in Abies percentages may be the result of increased humidity of air and soil (Tinner and Lotter, 2006; Pidek et al., 2013).

The cold Older Holsteinian Oscillation in the Brus palaeolake was marked by the development of aquatic flora and rush vegetation and abundant growth of hydrophytes with floating leaves, like the water fern Salvinia natans, which covered the lake surface (Pidek, 2003). This enhanced eutrophication, which is also confirmed by the dominance of Najas minor and Najas marina, and the disappearance of mesotrophic Najas flexilis (Fig. 3; BR MAZ 6). The increased number of epiphytic diatoms (various taxa of Fragilaria, Cymbella ehrenbergii and Martyana martyi) at the expense of the planktonic ones, indicate a lowering of the water level (Khursevich et al., 2003; Table 2). Abundant occurrence of Pediastrum simplex var. simplex also confirms the eutrophic conditions in the lake. The younger part of the zone is marked by the first occurrence of nympheids (Pidek, 2003), confirming the low water level and taking away light for diatoms, the amount of which decreased considerably in the following zone.

Br-8 Abies-Carpinus-Alnus L PAZ. The role of fir was important in the mixed forests at the beginning of the zone, but later Carpinus took over. Dry-ground oak-hornbeam forests with lime spread over vast areas, while the spatial extent of fir forests was reduced. New rise in the values of Alnus, and the slight increase in Taxus percentages probably provide evidence of repeated expansion of alder and yew.

The pollen data are in agreement with the macrofossil record of BR MAZ 6 Najas marina-N. minor-Ranunculus sceleratus-(Pinaceae-A. glutinosa). The eutrophic state of the lake is indicated by the dominance of Najas minor and Najas marina (Thiébaut, 2008) and the disappearance of mesotrophic Najas flexilis. Najas marina requires an average water temperature in July higher than $15^{\circ} \mathrm{C}$ (Lotter, 1988). The belt of rushes remained in the vestigial form with $C$. rostrata. It is also possible that peat bogs may have disappeared (disappearance of remains). The remains of Alnus glutinosa, Urtica dioica and Ranunculus sceleratus indicate a water-level rise and the presence of uncovered, periodically flooded shores, typical for alder carrs.

Br-9 Abies-Corylus-Quercus-/Carpinus/ L PAZ. Fir forests occupied again more extensive areas (Abies pollen up to $30 \%$ ). These were probably fir forests with spruce and only a small admixture of other trees. The values of Carpinus decreased considerably, after which Abies communities spread again over different habitats. This spread covers the climate optimum associated with the highest temperatures and maritime climate. Pollen values of Corylus and Quercus reached their absolute maxima indicating the spreading of dry-ground forests, in which oak was predominant, and hornbeam with lime accounted for a small admixture. A repeated spread of ash-elm riverine forests is manifested by the rising pollen values of Fraxinus, Ulmus and Taxus.

The climate optimum was also marked by a slight increase in water level, as inferred by the increase of planktonic diatoms, like Aulacoseira ambigua and $A$. granulata. Both these taxa, as well as several benthonic (e.g., Navicula oblonga, Amphora libyca and Anomoeoneis sphaerophora) and epiphytic diatoms, like Cymbella ehrenbergii and Epithemia zebra, indicate warm waters (Table 2; Khursevich et al., 2003). 
BR MAZ 7 Carex rostrata-Typha-Schoenoplectus lacustris-Cyperus fuscus-Nuphar-Najas marina-(A. glutinosa-Urtica dioica) - older part. The development of alder carr is evidenced by frequent appearances of fruits of Alnus glutinosa, Salix and Urtica dioica, and sporangia of Thelypteris palustris. It was probably a community similar to the modern Carici elongatae-Alnetum s.l. (Matuszkiewicz, 2001). Periodic lowering of the water levels uncovered the edges of the lake, where Ranunculus sceleratus and extinct $R$. gailensis were growing; these taxa are characteristic of swampy and periodically flooded shores of highly eutrophic reservoirs (Stachowicz-Rybka, 2011). The expansion of $C$. rostrata and Schoenoplectus lacustris, with a frequent occurrence of Typha, suggests a strong decrease in water level, which is also confirmed by a significant representation of Nympheids. They were accompanied by tolerant shallow water taxa, such as Lemna trisulca, Azolla filiculoides and Salvinia natans, characteristic for shallow and warm reservoirs of the Middle Pleistocene (Mamakowa and Velichkevich, 1993; Stachowicz-Rybka, 2011). The reservoir was eutrophic/mesotrophic, as indicated by the strong representation of Najas marina seeds (Thiébaut, 2008). In the final stage of this zone, the $\mathrm{pH}$ was probably lower (dystrophisation), as suggested by the appearance of, i.a., Comarum palustre. The complete disappearance of Cristatella mucedo might suggest a decrease in $\mathrm{pH}$ at that time, too. Alternatively, the decrease of the latter species can be attributed to the spreading of Nympheids, which reduced the amount of light in the water column.

Br-10 Abies-Alnus-Carpinus-IFilicales/ L PAZ. The maximum of $A$ bies pollen values (43\%) indicates the spreading of fir on diverse habitats, and the very high percentages of Alnus (up to $44 \%$ ) demonstrate that fir and alder communities predominated in this zone. These suggest a higher groundwater level.

The degradation of both riverine and dry-ground forests, and probably alder carr forests, is observable in the middle of the zone. It is evidenced by the continuous fall in the pollen values of Corylus, the temporal decrease in Carpinus, Quercus, Alnus and Ulmus percentages, the simultaneous increase in Pinus sylvestris t. and Taxus frequencies, and the continuous rise in Abies values. This zone may reflect changes influenced by the Younger Holsteinian Oscillation (Koutsodendris et al., 2013; Fig. 4).

The very high percentages of Filicales monolete spores throughout $\mathrm{Br}-10 \mathrm{~L} \mathrm{PAZ}$, particularly in its middle part (YHO), could be due to the alder community occurring near the lake. However, it is also very probable that a high proportion of ferns occurred in the fir forest. The rise in the pollen values of Pinus sylvestris t. and Picea in the youngest part of the zone resulted probably from the increased proportions of pine and spruce in fir forest communities due to soil impoverishment and acidification, which could have eliminated some Abies at that time.

Multi-species dry-ground forests with predominant Quercus still survived, and the role of Carpinus slightly increased. Pollen of Pterocarya, which typically occurs in the last part of the Holsteinian climate optimum, can be related to the survived patches of elm-ash riverine forests. Pollen of Pterocarya was found also in the Dethlingen profile in Germany (Koutsodendris et al., 2010) and in many sites of the Mazovian Interglacial deposits in Poland, e.g. in Olszewice (Sobolewska, 1956), Gościęcin (Środoń, 1957), Włodawa (Stachurska, 1957), Ossówka and Grabanów (Krupiński, 1995).

Rapid rise in the pollen values of Cyperaceae from the beginning of the zone can be related to herbaceous vegetation of alder carrs and mires overgrowing the lake. The $\mathrm{Br}-10 \mathrm{~L} P A Z$ corresponds to three macrofossil zones (BR MAZ 7 - younger part, BR 8 and BR 9).
BR MAZ 7 Carex rostrata-Typha-Schoenoplectus lacustris-Cyperus fuscus-Nuphar-Najas marina-(A. glutinosa-Urtica dioica) - younger part. A decrease in $\mathrm{pH}$ is confirmed by the appearance of Cladium mariscus in the younger part of the zone. This species occurs today most frequently in mesotrophic and shallow reservoirs and less frequently in oligo- and dystrophic ones (Piękoś-Mirkowa and Mirek, 2006). In the final phase of the zone, Lemna trisulca appeared frequently, which tolerates shallow-water and mesotrophic conditions (Thiébaut, 2008). There was also Azolla filiculoides, which is characteristic for shallow and warm reservoirs of the Middle Pleistocene (Mamakowa and Velichkevich, 1993; Stachowicz-Rybka, 2011). The frequent occurrence of Cyperus fuscus may indicate the existence of periodically drying places.

Several diatom genera (e.g., Fragilaria, Anomoeoneis, Navicula, Neidum, Amphora, Rhopalodia and Nitzschia) provide evidence for overgrowing and shallowing of the lake (Khursevich et al., 2003). The increasing number of epiphytic diatoms indicates growth of the macrophyte zone and confirms the shallowing of the lake. In the final stage of the zone, a drop in $\mathrm{pH}$ (dystrophisation) could have happened as suggested by the appearance of, i.a., Comarum palustre, disappearance of Cristatella mucedo (Fig. 3; BR MAZ 7), and the decrease in both diatoms and Pediastrum.

The following macrofossil zone BR MAZ 8 Typha sp.-S. lacustris-(A. glutinosa) correlates with the middle part of the $\mathrm{Br}-10 \mathrm{~L}$ PAZ and reflects the existence of a mesotrophic/eutrophic lake surrounded by an alder carr (fruits of Alnus glutinosa, nitrophilous Urtica dioica and Thelypteris palustris) with very shallow and eutrophic waters (Thiébaut, 2008). This is confirmed by the presence of Lemna trisulca and the dominance of rushes with Typha, Carex rostrata and Schoenoplectus lacustris. The disappearance of the majority of rush and aquatic plants may indicate a climatic changes related to the YHO. The disappearance of diatoms and green algae at that time was evidently associated with the final stage of shallowing of the lake.

BR MAZ 9 (A. glutinosa-U. dioica). Subsequently, as the water level continued to decrease, wetlands may have been the only habitats that remained. The alder carr hosted nitrophilous species, e.g. Sambucus and Rubus. The end of the interglacial's mesocratic phase was characterized by the almost complete disappearance of aquatic and swamp plants (Fig. 3; BR MAZ 9).

\section{TELOCRATIC PHASE}

Br-11 Pinus-Larix L PAZ. Strong transformation of the forests occurred in the last part of the interglacial. Pine communities with larch and birch spread and probably encroached on the habitats of all other forest communities. Alder carrs, fir communities, and patches of multi-species mixed forests still resisted the expansion of pine. In the younger part of the zone, pine forests with birch and larch occupied almost all habitats. These changes provide evidence for a considerably cooler and more continental climate.

The considerable increase in the NAP values (up to $31 \%$ ) in the younger part of the zone indicates that the role of open communities became important. The rise in the spore percentages of Sphagnum indicates that peatbogs spread, too.

The Br-11 L PAZ corresponds to BR MAZ $10 \mathrm{Ty}$ pha sp.-(Betula nana-B. humilis-B. S. Albae), which reflects a slight water-level rise, although the reservoir remained shallow. Nympheids, Batrachium and significant amounts of $P$. boryanum var. boryanum appeared again (Khursevich et al., 2003). 


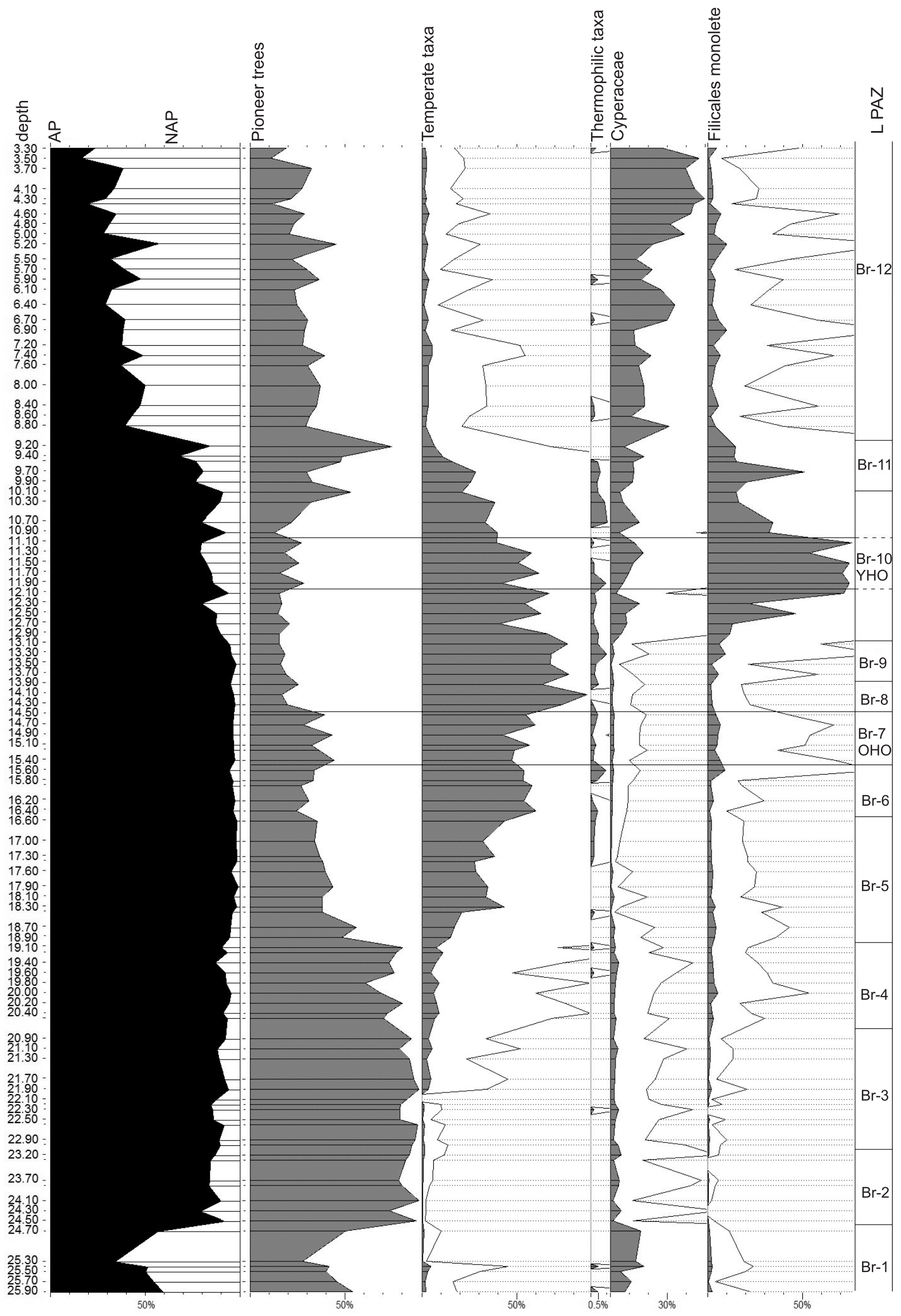

Fig. 4. Combined percentages of selected groups of taxa: "Pioneer trees", including Pinus and Betula; "Temperate taxa", including: Abies, Acer, Carpinus, Corylus, Fraxinus, Picea, Quercus, Taxus, Tilia and UImus; "Thermophilic taxa", including: Buxus, Celtis, Frangula, Hedera, Ilex, Ligustrum, Pterocarya, Viburnym, Viscum and Vitis; AP - Arboreal Pollen, NAP - Non-Arboreal Pollen 
Water-level changes correlation based on macrofossil data from the sites of Brus (BR L MAZ, Polesie Region - this paper) and Nowiny Zukowskie (NZ̈5 L MAZ, Lublin Upland, Hrynowiecka and Szymczyk, 2011; Hrynowiecka and Obidowicz, 2011)

\begin{tabular}{|c|c|c|c|c|c|c|c|}
\hline \multirow{2}{*}{\multicolumn{2}{|c|}{$\begin{array}{c}\text { Chrono- } \\
\text { stratigraphy }\end{array}$}} & \multicolumn{2}{|r|}{ BR L MAZ } & \multirow{2}{*}{$\begin{array}{c}\text { Water-level } \\
\text { changes } \\
\text { based on } \\
\text { BR L MAZ } \\
\qquad\end{array}$} & \multicolumn{2}{|r|}{ NŻ05 L MAZ } & \multirow{2}{*}{$\begin{array}{c}\text { Water-level } \\
\text { changes based } \\
\text { on NŻ05 L MAZ } \\
\uparrow\end{array}$} \\
\hline & & 11 & Callitriche autumnalis-Chara & & 8 & $\begin{array}{l}\text { Batrachium-Callitriche } \\
\text { autumnalis }\end{array}$ & \\
\hline \multirow{10}{*}{ 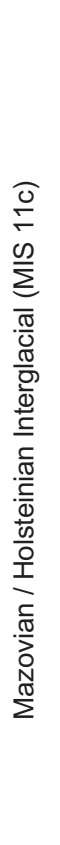 } & \multirow{2}{*}{$\begin{array}{l}\text { Telocratic } \\
\text { (Late) }\end{array}$} & \multirow[t]{2}{*}{10} & \multirow[t]{2}{*}{$\begin{array}{l}\text { Typha-(Betula nana-B. humilis- } \\
\text { B. s. Albae) }\end{array}$} & \multirow[t]{2}{*}{$\begin{array}{l}\text { slight } \\
\text { increase }\end{array}$} & 7 & $\begin{array}{c}\text { Batrachium-Nuphar } \\
\text { pumila-Nymphaea alba- } \\
\text { Potamogeton } \\
\text { natans-Menyanthes trifoli- } \\
\text { ata-(Larix-Betula humilis) }\end{array}$ & $\begin{array}{l}\text { slight } \\
\text { increase }\end{array}$ \\
\hline & & & & & 6 & $\begin{array}{l}\text { C. rostrata-Menyanthes trifoli- } \\
\text { ata-E. vaginatum-(Betula s. } \\
\text { Albae-Pinus sylvestris) }\end{array}$ & shallow \\
\hline & \multirow{5}{*}{$\begin{array}{c}\text { Mesocratic } \\
\text { (Middle) }\end{array}$} & 9 & (Alnus glutinosa-Urtica dioica) & $\downarrow$ & 5 & \multirow{2}{*}{$\begin{array}{c}\text { A. interglacialis-Eriophorum } \\
\text { vaginatum-Brasenia } \\
\text { borysthenica-Aldrovanda } \\
\text { dokturovskyi }\end{array}$} & \multirow{3}{*}{$\begin{array}{l}\text { shallow } \\
\text { (peat bog) }\end{array}$} \\
\hline & & 8 & $\begin{array}{l}\text { Typha-Schoenoplectus lacustris-(Alnus } \\
\text { glutinosa) }\end{array}$ & shallow & & & \\
\hline & & 7 & $\begin{array}{l}\text { Carex rostrata-Typha-Schoenoplectus } \\
\text { lacustris-Cyperus fuscus-Nuphar-Najas } \\
\text { marina-(Alnus glutinosa-Urtica dioica) }\end{array}$ & $\downarrow$ & 4 & $\begin{array}{c}\text { Aracites } \\
\text { interglacialis-Dulichium } \\
\text { arundinaceum }\end{array}$ & \\
\hline & & 6 & $\begin{array}{l}\text { Najas marina-Najas minor- Ranunculus } \\
\text { sceleratus-(Pinaceae-Alnus glutinosa) }\end{array}$ & $\downarrow$ & 3 & $\begin{array}{c}\text { Carex gracilis-Schoenoplectus } \\
\text { lacustris-Nuphar lutea-(Betula s. } \\
\text { Albae-Picea) }\end{array}$ & $\downarrow$ \\
\hline & & 5 & (Pinaceae-Alnus glutinosa) & high & 2 & $\begin{array}{c}\text { Isoëtes lacustris-Potamogeton } \\
\text { natans }\end{array}$ & 个high \\
\hline & \multirow[b]{3}{*}{$\begin{array}{c}\text { Protocratic } \\
\text { (Early) }\end{array}$} & 4 & (Betula s. Albae-Pinaceae) & $\downarrow \uparrow$ unstable & & \multirow[b]{3}{*}{$\begin{array}{c}\text { Carex rostrata-Potamogeton } \\
\text { natans-Potamogeton } \\
\text { rutilus-(Betula s. Albae-Urtica } \\
\text { dioica) }\end{array}$} & \multirow[b]{3}{*}{ shallow } \\
\hline & & 3 & Typha-Phragmites australis-(Betula s. Albae) & shallow & & & \\
\hline & & 2 & Chara-(Betula nana-Betula s. Albae) & shallow & 1 & & \\
\hline \multicolumn{2}{|c|}{$\begin{array}{l}\text { Late Sanian 2/ } \\
\text { Elsterian Gl. }\end{array}$} & 1 & sporadic plant fossils & shallow & - & - & - \\
\hline
\end{tabular}

The belt of rushes was formed mainly by Typha and C. rostrata, but none was as important as in the previous zones. Alder carr still overgrew the edges of the reservoir, however, Betula communities also played an important role in this habitat. The occurrence of patches of peat bogs is confirmed by fruits and fruit scales of Betula nana and $B$. humilis. The lake was mesotrophic at that time as indicated by the presence of Myriophyllum verticillatum (Thiébaut, 2008), Cladium mariscus, and Potamogeton filiformis. The water was cool and highly transparent, rich in $\mathrm{CaCO}_{3}$, with $\mathrm{pH}>7$ (presence of $P$. filiformis, Lang, 1994). Relatively numerous scleroids of Cenococcum geophillum indicate the onset of climate deterioration (Fernandez et al., 2013).

\section{EARLY LIWIECIAN (=SAALIAN) GLACIATION}

Br-12 NAP-Betula nana-Salix-/Juniperus/ L PAZ. A decrease in the frequencies of all trees and the simultaneous rise in the percentages of Artemisia and Poaceae (both to a maximum $>20 \%$ ) as well as Cyperaceae (max. 50\%) indicate that forests were replaced by open communities. Single pine trees could have entered into the composition of birch-larch patches, but it seems that at least part of Pinus sylvestris t. pollen grains in open landscape may have been derived from distant areas. In open landscapes, bisaccate pollen grains of pine can be eas- ily transported over tens or more kilometres (Rousseau et al., 2008). The occurrence of redeposited sporomorphs indicates lack of forest cover, which enhanced soil erosion. The $\mathrm{Br}-12 \mathrm{~L}$ PAZ corresponds to BR MAZ 11 Callitriche autumnalis-Chara. In this zone, the water level continued to rise allowing for the development of communities with Chara and Cristacella. In contrast, however, the presence of Callitriche autumnalis and Batrachium indicate still relatively shallow waters. The belt of rushes was in regression at that time and covered mainly by Typha and communities with Carex rostrata. Peat bogs developed again, as indicated by numerous stems and leaves of Sphagnum. Numerous ephippia of Daphnia indicate deterioration of climatic conditions, which forced representatives of Cladocerans to produce survival forms. The waters of palaeolake cooled down, as evidenced by a significant amount of Pediastrum kawraiskyi and Botryococcus pila (Pidek, 2003), which are indicators of cold and oligotrophic lake waters (Jankovská and Komárek, 2000).

\section{DISCUSSION}

The Holsteinian Interglacial is considered the longest and warmest Pleistocene terrestrial interglacial in central Europe (Müller, 1974; Krupiński, 2000; Raynaud, 2005; Kühl and Litt, 
2007; Head and Gibbard, 2015 and references therein). It lasted 15-18 ky in the terrestrial domain (Müller, 1974; Kühl and Litt, 2007; Koutsodendris et al., 2010) or even 25-30 ky in the marine domain (Head and Gibbard, 2016 and references therein). The Holsteinian is characterized by a unique pattern of vegetation succession in central Europe, starting from boreal birch and pine forests, followed by spruce and alder expansion with admixture of ash and elm. The pattern of climate amelioration in the Polesie region, based on investigations of the Brus record, is similar to the pattern reconstructed for the Holsteinian based on Nowiny Żukowskie (Hrynowiecka-Czmielewska, 2010; Hrynowiecka and Winter, 2016) and other pollen data from Ossówka, Biała Podlaska, Woskrzenice (e.g., Krupiński, 1984-1985, 1995; Krupiński and Lindner, 1991; Bińka and Nitychoruk, 1995, 1996) and Wilczyn (Bińka et al., 1997; Szymanek, 2013). This pattern agrees also with that obtained from German profiles (e.g., Eissmann, 2002; Diehl and Sirocko, 2007; Koutsodendris et al., 2010). The beginning of the Holsteinian Interglacial is recorded in the tree succession of boreal elements indicating high seasonality (Table 2). However, the presence of Typha latifolia in the lake suggests that the July temperature at the very beginning of the interglacial was not lower than $14^{\circ} \mathrm{C}$. The presence of macrofossils of Typha latifolia seems to support the opinion of Szafer (1953) that the response of aquatic plants to the climatic warming during the protocratic period is faster than the reaction of terrestrial plants, and especially trees. Both the Brus and Nowiny Żukowskie fossil lakes started their existence as oligotrophic, shallow postglacial lakes (Table 3).

The subsequent stage of vegetation development is marked by the rapid spread of yew communities. It is especially important for palaeoclimate considerations, as the eastern boundary of the modern extent of Taxus baccata is in line with the limit of maritime climate influence (West, 1962; Środoń, 1975). The water level increased considerably in both the fossil lakes (Table 3). The subsequent dramatic fall in Taxus pollen percentages in the pollen diagram (Fig. 2) suggests particularly low winter temperatures (Geyh and Müller, 2005, 2007) and is followed by the sudden regression of thermophilous trees accompanied by the decrease in spruce and alder, and the distinct spread of pine. The increase in Pinus percentages is very distinct in the Brus profile and suggests that the climate became more dry and continental. This drier and colder climatic oscillation is recorded in many sites of the Mazovian Interglacial in Poland, e.g. in Gościęcin (Środoń, 1957), Krępiec (Janczyk-Kopikowa, 1981), Biała Podlaska, Komarno, Ossówka (Krupiński, 1984-1985, 1995; Krupiński and Lindner, 1991), Woskrzenice and Kaliłów (Bińka and Nitychoruk, 1995, 1996), and Konieczki (Nita, 1999). It can be also found in other sites in Europe north of $50^{\circ}$ latitude. According to Koutsodendris et al. (2012), the reason for that was the stronger influence of the Siberian High in Eastern Europe, which resulted in the drop of both temperature (mainly winter temperature) and moisture availability. This regression phase, named $\mathrm{OHO}$, occurred at $\sim 6000 \pm 500$ years (calculations based on varved sediments of the Dethlingen profile) after the onset of the Holsteinian reforestation (Koutsodendris et al., 2012). The cited authors conclude that the overall picture of the $\mathrm{OHO}$, including the reasons of its occurrence, seem to resemble the 8.2 ky climate event in the Holocene.

Koutsodendris et al. $(2012,2013)$ stressed also the changes in diatom communities in the Dethlingen profile during the $\mathrm{OHO}$. The assemblages were dominated by Fragillaria spp. and other benthic diatoms. The same feature is observable in the Brus diatom assemblages, where different epiphytic Fra- gillaria species dominate during the Br-7 LPAZ (Khursevich et al., 2003), which correlates with the OHO. Subsequently, the diatom assemblage changed considerably, with significant decrease in planktonic species of diatom taxa.

The Holsteinian Interglacial climate optimum, which developed after the regression phase of the $\mathrm{OHO}$, is expressed by the encroachment of fir and hornbeam into the forests accompanied by numerous plant indicators of warm and humid climates. The Br-8-Br-10 L PAZ from the Brus diagram and NŻ05 8 L PAZ from the Nowiny Żukowskie diagram (Hrynowiecka-Czmielewska, 2010) evidence peak optimum climate conditions associated with the spread of multi-species communities of fir, and dry-ground and riverine thermophilous forests. Various forest communities and thermophilous shrubs, which occurred in eastern Poland in this interglacial interval, were characterized by the presence of taxa indicating warm (mean July temperature $>20^{\circ} \mathrm{C}$; Table 2) and humid climate, e.g. Buxus, Ligustrum, Viscum and Vitis.

Climate of the last part of the interglacial (zones $\mathrm{Br}-10 \mathrm{~L}$ PAZ and the younger part of NŻ05 8 L PAZ subzone $8 \mathrm{e})$ is well-characterized by the presence of thermophilous Pterocarya and Buxus in forest communities. In both the Brus and Nowiny Żukowskie palaeobotanical data, they testify to increased climate humidity (Zagwijn, 1996; Granoszewski, 2003) and high temperatures. The same climatic significance has the water fern Azolla that was present in the Brus palaeolake in the younger part of the BR MAZ 7, so the lake must have been warm and eutrophic. The Brus and Nowiny Żukowskie pollen diagrams show the occurrence of changes at that time, which may be related to the $\mathrm{YHO}$ event. They are marked by strong oceanic climate influence (Table 2; central part of the zones Br-10 L PAZ and NŻ05 8c L PAZ). This is reflected in Brus especially in the Abies expansion, huge amount of ferns, and the increased proportion of Cyperaceae. In Western Europe, the climate conditions were dryer than the $\mathrm{OHO}$. Koutsodendris et al. $(2010,2013)$ consider it as the effect of rising summer temperature and decreasing amount of precipitation. Hrynowiecka and Winter (2016) stress that, in Dethlingen, the $\mathrm{YHO}$ is not related to the expansion of Abies after the Carpinus decline, in contrast to the Brus and Nowiny Żukowskie sites.

The rise in Pinus sylvestris t. and Larix values, and the simultaneous decrease in the frequencies of all thermophilous taxa in the Br-11 L PAZ provide evidence of climate cooling and drying. However, the occurrence of Pterocarya in the middle part of the $\mathrm{Br}-11 \mathrm{~L}$ PAZ indicates that the climate was relatively warm at first, and a mixed multi-species forest with predominant fir survived the first phase of gradual cooling. It can be supposed that the mean temperature of the warmest month was decreasing from $\sim 17$ to $\sim 10^{\circ} \mathrm{C}$ at the onset of the next pollen zone (Br-12 L PAZ and NŻ05 12 L PAZ), which marks the beginning of the Liwiecian/Saalian Glaciation.

\section{CONCLUSIONS}

Macrofossil data from the lacustrine deposits of the Brus profile (E Poland) reveal a typical palaeolake succession of the Mazovian/Holsteinian Interglacial, which started developing as early as the Late Glacial of the Sanian 2/Elsterian Glaciation.

The palaeolake in Brus was shallow and oligotrophic during the early interglacial intervals and became a large meso-eutrophic water reservoir towards the climate optimum. During the optimum the palaeolake was overgrown by reed/swamp 
vegetation, and alder carrs developed on its margins. At the beginning of the Liwiecian/Saalian Glaciation, the lake became again a shallow mesotrophic reservoir.

The macrofossil succession is in line with pollen data and enables comparison with the complete palaeobotanical record (both pollen and macrofossil data) of Nowiny Żukowskie, which is situated $\sim 80 \mathrm{~km}$ away in eastern Poland.

The high sedimentation rate in the Brus profile (21 m of lacustrine and peat deposits) enabled tracing the $\mathrm{OHO}$ and $\mathrm{YHO}$ climatic events that are also reflected in the Nowiny Żukowskie palaeobotanical data.
The palaeobotanical record of the $\mathrm{OHO}$ and $\mathrm{YHO}$ agrees with that from Dethlingen (N Germany; Koutsodendris et al., 2012 , 2013), confirming the wide distribution of both these climate oscillations in the lowlands of central-eastern Europe.

Acknowledgements. The authors are grateful to A. Koutsodendris, H. Winter, and an anonymous reviewer for their constructive comments. The editors of Geological Quarterly are also thanked for their valuable comments that helped to improve the earlier version of the manuscript.

\section{REFERENCES}

Ashton, N., Lewis, S.G., Parfitt, S.A., 2008. New evidence for complex climate change in MIS 11 from Hoxne, Suffolk, UK. Quaternary Science Reviews, 27: 652-668.

Bennike, O., Houmark-Nielsen, M., Bocher, J., Heinberg, E.O., 1994. A multi-disciplinary macrofossil study of Middle Weichselian sediments at Kobbelgard, Mon, Denmark. Palaeogeography, Palaeoclimatology, Palaeoecology, 111: 1-15.

Bińka, K., Nitychoruk, J., 1995. Mazovian (Holsteinian) lake sediments at Woskrzenice near Biała Podlaska. Geological Quarterly, 39 (1): 109-120.

Bińka, K., Nitychoruk, J., 1996. Geological and palaeobotanical setting of interglacial sediments at the Kaliłów site in southern Podlasie. Geological Quarterly, 40 (2): 269-282.

Bińka, K., Lindner, L., Nitychoruk, J., 1997. Geologic-floristic setting of the Mazovian Interglacial sites in Wilczyn and Lipnica in Southern Podlasie (eastern Poland) and their palaeogeographic connections. Geological Quarterly, 41 (3): 381-394.

Birks, H.H., 2000. Aquatic macrophyte vegetation development in Kråkenes Lake, western Norway, during the late-glacial and early-Holocene. Journal of Paleolimnology, 23: 7-19.

Brauer, A., Allen, J.R.M., Mingram, J., Dulski, P., Wulf, S., Huntley, B., 2007. Evidence for Last Interglacial chronology and environmental change from southern Europe. Proceedings of the National Academy of Sciences USA, 104: 450-455.

Brem, M., 1953. Interglacial flora from Ciechanki Krzesimowskie by Łęczyca (in Polish with English summary). Acta Geologica Polonica, 3: 475-479.

Buraczyński, J., Wojtanowicz, J., 1982. Objaśnienia do Szczegółowej Mapy Geologicznej Polski w skali 1:50000, ark. Kołacze (716) (in Polish). Wyd. Geol., Warszawa.

de Beaulieu, J.-L., Andrieu-Ponel, V., Reille, M., Grüger, E., Tzedakis, C., Svobodova, H., 2001. An attempt at correlation between the Velay pollen sequence and the Middle Pleistocene stratigraphy from central Europe. Quaternary Science Reviews, 20: 1593-1602.

Desprat, S., Sánchez-Goñi, M.F., Turon, J.-L., McManus, J.F., Loutre, M.F., Duprat, J., Malaizé, B., Peyron, O., Peypouquet, J.-P., 2005. Is vegetation responsible for glacial inception during periods of muted insolation changes. Quaternary Science Reviews, 24: 1361-1374.

Diehl, M., Sirocko, F., 2007. A new Holsteinian record from the dry Maar at Döttingen (Eifel). In: The Climate of Past Interglacials, Developments in Quaternary Science (eds. F. Sirocko, M. Claussen, M.F. Sánchez-Goñi and T. Litt): 397-416. Elsevier, Amsterdam.

Eide, W., Birks, H.H., Bigelow, H.N., Peglar, M.S., Birks, H.J.B., 2006. Holocene forest development along the Setesdal valley, southern Norway, reconstructed from macrofossil and pollen evidence. Vegetation History and Archaeobotany, 15: 65-85.
Eissmann, L., 2002. Quaternary geology of eastern Germany (Saxony, Saxon-Anhalt, South Brandenburg, Thüringia), type area of the Elsterian and Saalian stages in Europe. Quaternary Science Reviews, 21: 1275-1346.

Erdtman, G., 1960. The acetolysis method. Svensk Botanisk Tidskrift, 54: 561-564.

Fernandez, C.W., McCormack, M.L., Hill, J.M., Pritchard, S.G., Koide, R.T., 2013. On the persistence of Cenococcum geophilum ectomycorrhizas and its implications for forest carbon and nutrient cycles. Soil Biology and Biochemistry, 65: 141-143.

Geyh, M.A., Müller, H., 2005. Numerical 230Th/U dating and a palynological review of the Holsteinian/Hoxnian interglacial. Quaternary Science Reviews, 24: 1861-1872.

Geyh, M.A., Müller, H., 2007. Palynological and geochronological study of the Holsteinian/Hoxnian/Landos interglacial. In: The Climate of Past Interglacials, Developments in Quaternary Science (eds. F. Sirocko, M. Claussen, M.F. Sánchez-Gońi and T. Litt): 387-396. Elsevier, Amsterdam.

Granoszewski, W., 2003. Late Pleistocene vegetation history and climatic changes at Horoszki Duże, eastern Poland: a palaeobotanical study. Acta Palaeobotanica, Suppl., 4: 3-95.

Head, M.J., Gibbard, P.L., 2015. Early-Middle Pleistocene transitions: linking terrestrial and marine realms. Quaternary International, 389: 7-46.

Hrynowiecka-Czmielewska, A., 2010. History of vegetation and climate of the Mazovian (Holsteinian) Interglacial and the Liviecian (Saalian) Glaciation on the basis of pollen analysis of palaeolake sediments from Nowiny Żukowskie, SE Poland. Acta Palaeobotanica, 50: 17-54.

Hrynowiecka, A., Obidowicz, A., 2011. The attempt to define reference conditions for Mazovian/Holsteinian Interglacial lacustrine-peat bog sediments from Nowiny Żukowskie (SE Poland) (in Polish with English summary). Studia Limnologica et Telmatologica, 5: 13-22.

Hrynowiecka, A., Szymczyk, A., 2011. Preliminary results of comprehensive palaeobotanical studies of peat bog sediments from the Mazovian (Holstein) interglacial at the site of Nowiny Żukowskie (SE Poland). Bulletin of Geography, Physical Geography Series, 4: 21-47.

Hrynowiecka, A., Winter, H., 2016. Palaeoclimatic changes in the Holsteinian Interglacial (middle Pleistocene) on the basis of indicator-species method - palynological and macrofossils remains from Nowiny Żukowskie site (SE Poland). Quaternary International, 409: 255-269.

Isarin, R.F.B., Bohncke, S.J.P., 1999. Mean July temperatures during the Younger Dryas in Northwestern and Central Europe as Inferred from Climate Indicator Plant Species. Quaternary Research, 51: 158-173. 
Iversen, J., 1954. The Late-glacial flora of Denmark and its relation to climate and soil. Danmarks Geologiske Undersøgelse, 2: 87-119.

Janczyk-Kopikowa, Z., 1981. Pollen analysis of the Pleistocene sediments at Kaznów and Krępiec (in Polish with English summary). Biuletyn Instytutu Geologicznego, 321: 249-258.

Jankovska, V., Komárek, J., 2000. Indicative value of Pediastrum and other coccal green algae in palaeoecology. Folia Geobotanica, 35: 59-82.

Khursevich, G.K., Pidek, I.A., Fedenya, S.A., 2003. Environment changes in a fossil lake at Brus (Lublin Polesie SE Poland) based on palaeoalgological data. Annales Universitatis Mariae Curie-Skłodowska Lublin Polonia, 58: 107-120.

Kolstrup, E., 1979. Herbs as July temperature indicators for parts of the Peniglacial and the Late-glacial in the Netherland. Geologie en Mijnbouw, 59: 337-380.

Kolstrup, E., 1980. Climate and stratigraphy in northwestern Europe between $30000 \mathrm{BP}$ and $13000 \mathrm{BP}$ with special reference to the Netherlands. Mededelingen Rijks Geologische Dienst, 32: 181-253.

Koutsodendris, A., Müller, U.C., Pross, J., Brauer, A., Kotthoff, U., Lotter, A.F., 2010. Vegetation dynamics and climate variability during the Holsteinian interglacial based on a pollen record from Dethlingen (northern Germany). Quaternary Science Reviews, 29: 3298-3307.

Koutsodendris, A., Brauer, A., Pälike, H., Müller, U.C., Dulski, P., Lotter, A.F., Pross., J., 2011. Sub-decadal- to decadal-scale climate cyclicity during the Holsteinian interglacial (MIS 11) evidenced in annually laminated Sediments. Climate of the Past, 7: 987-999.

Koutsodendris, A., Pross, J., Müller, U.C., Brauer, A., Fletcher, W.J., Kühl, N., Kirilova, E., Verhagen, F.T.M., Lücke, A., Lotter, A.F., 2012. A short-term climate oscillation during the Holsteinian interglacial (MIS 11c): an analogy to the $8.2 \mathrm{ka}$ climatic event? Global and Planetary Change, 92/93: 224-235.

Koutsodendris, A., Lotter, A.F., Kirilova, E., Verhagen, F.T.M., Brauer, A., Pross, J., 2013. Evolution of a Holsteinian (MIS 11c) palaeolake based on a 12-kyr-long diatom record from Dethlingen (northern Germany). Boreas, 42: 714-728.

Krauss, A., Mycielska-Dowgiałło, E., Szczepanek, K., 1965. Preliminary data on the age of the deposits in the Vistula River valley near Tarnobrzeg (in Polish with English summary). Przeglad Geologiczny, 13: 275-279.

Krupiński, K.M., 1984-1985. Wyniki wstępnych badań palinologicznych osadów interglacjału mazowieckiego w Białej Podlaskiej (in Polish). Rocznik Międzyrzecki, 16-7: 144-171.

Krupiński, K.M., 1995. Pollen stratigraphy and succession of vegetation during the Mazovian Interglacial (in Polish with English summary). Acta Universitatis Lodziensis, 70: 1-200.

Krupiński, K.M., 2000. Palynostratigraphic correlation of deposits of the Mazovian interglacial in Poland (in Polish with English summary). Prace Państwowego Instytutu Geologicznego, 169: $1-61$.

Krupiński, K.M., Lindner, L., 1991. Interglacial flora at Komarno near Biała Podlaska, Eastern Poland (in Polish with English summary). UAM Geografia, 50: 511-518.

Lang, G., 1994. Quartäre Vegetationsgeschichte Europas. Gustav Fischer Verlag, Jena.

Lee, J.R., Rose, J., Hamblin, R.J.O., Moorlock, B.S.P., 2004. Dating the earliest lowland glaciation of eastern England: a pre-MIS 12 early Middle Pleistocene Happisburgh glaciation. Quaternary Science Reviews, 23: 1551-1566.

Lotter, A.F., 1988. Paläoökologische und paläolimnologische studie des rotsees bei luzern. Pollen-, grossrest-, diatomen- und sedimentanalytische Untersuchungen. Dissertationes Botanicae, 124: 1-187.

Matuszkiewicz, W., 2001. Przewodnik do oznaczania zbiorowisk roślinnych Polski (in Polish). Vademecum Geobotanicum, PWN, Warszawa.
Mamakowa, K., Velichkevich, F.Yu., 1993. Exotic plants in the floras of the Mazovian (Alexandrian) Interglacial of Poland and Belarus. Acta Palaeobotanica, 33: 305-319.

Müller, H., 1974. Pollenanalytische Untersuchungen und Jahresschichtenzählungen an der holstein-zeitlichen Kieselgur von Munstere Breloh. Geologisches Jahrbuch A, 21: 107-140.

Müller, U.C., Klotz, S., Geyh, M.A., Pross, J., Bond, G.C., 2005 Cyclic climate fluctuations during the Last Interglacial in central Europe. Geology, 33: 449-452.

Nalepka, D., Walanus, A., 2003. Data processing in pollen analysis. Acta Palaeobotanica, 43: 125-134.

Nitychoruk, J., Bińka, K., Hoefs, J., Ruppert, H., Schneider, J., 2005. Climate reconstruction for the Holsteinian Interglacial in eastern Poland and its comparison with isotopic data from Marine Isotope Stage 1. Quaternary Science Reviews, 24: 631-644.

Nitychoruk, J., Bińka, K., Ruppert, H., Schneider, J., 2006 Holsteinian Interglacial - Marine Isotope Stage 11? Quaternary Science Reviews, 25: 2678-2681.

Økland, K.A., Økland, J., 2000. Freshwater bryozoans (Bryozoa) of Norway: distribution and ecology of Cristatella mucedo and Paludicella articulate. Hydrobiologia, 421: 1-24.

Piękoś-Mirkowa, H., Mirek, Z., 2006. Rośliny chronione (in Polish). In: Flora Polski. Oficyna Wydawnicza Multico, Warszawa.

Pidek, I.A., 2003. Mesopleistocene vegetation history in the northern foreland of the Lublin Upland based on palaeobotanical studies of the profiles from Zdany and Brus sites. Maria Curie-Skłodowska University Press, Lublin.

Pidek, I.A., 2013. Pollen-based vegetation and climate reconstruction of the Ferdynandovian sequence from Łuków (E Poland). Acta Palaeobotanica, 53: 115-138.

Pidek, I.A., Terpiłowski, S., Małek, M., 2011. Succession of the Mazovian Interglacial near Łuków (E Poland): palynostratigraphic and palaeogeographic approach. Geologija, 53: 27-35.

Pidek, I.A., Svitavská-Svobodová, H., van der Knaap, W.O., Magyari, E., 2013. Pollen percentage thresholds of Abies alba based on 13-year annual records of pollen deposition in modified Tauber traps: perspectives of application to fossil situations. Review of Palaeobotany and Palynology, 195: 26-36.

Reille, M., de Beaulieu, J.-L., Svobodova, H., Andrieu-Ponel, V., Goeury, C., 2000. Pollen stratigraphy of the five last climatic cycles in a long continental sequences from Valey (Massif Central, France). Journal of Quaternary Science, 15: 665-685.

Rousseau, D.-D., Schevin, P., Ferrier, J., Jolly, D., Andreasen, T., Ascanius, S.E., Hendriksen, S.-E., Poulsen, U., 2008. Long-distance pollen transport from North America to Greenland in spring. Journal of Geophysical Research, 113: G02013.

Ruddiman, W.F., 2005. Cold climate during the closest stage 11 analog to recent millennia. Quaternary Science Reviews, 24: 1111-1121.

Sobolewska, M., 1956. Pleistocene vegetation of Syrniki on the River Wieprz (in Polish with English summary). Biuletyn Instytutu Geologicznego, 100: 143-192.

Sobolewska, M., 1977. Interglacial vegetation of Stanowice near Rybnik (Upper Silesia) (in Polish with English summary). Acta Palaeobotanica, 18: 1-16.

Stachowicz-Rybka, R., 2011. Flora and vegetation changes on the basis of plant macroremains analysis from an early Pleistocene lake of the Augustow Plain, NE Poland, Acta Palaeobotanica, 51: 39-104.

Stachurska, A., 1957. Interglacial flora from Włodawa on the Bug river (in Polish with English summary). Biuletyn Państwowego Instytutu Geologicznego, 118: 61-80.

Szafer, W., 1953. Pleistocene stratigraphy of Poland from the floristical point of view (in Polish with English summary). Rocznik Polskiego Towarzystwa Geologicznego, 11: 1-238.

Szymanek, M., 2013. Palaeoecology of the Holsteinian lake in vicinity of Wilczyn (Eastern Poland) based on molluscan studies. Geological Quarterly, 57: 637-648. 
Środoń, A., 1957. Interglacial flora from Gościęcin near Koźle (in Polish with English summary). Biuletyn Instytutu Geologicznego, 118: 7-60.

Środoń, A., 1975. Historia cisa na naszych ziemiach. In: Cis pospolity Taxus baccata L. (in Polish). Nasze drzewa leśne, Monografie popularnonaukowe, tom 3 (ed. S. Białobok): 7-17. PWN, Warszawa-Poznań.

Thiébaut, G., 2008. Phosphorous and aquatic plants. In: The Ecophysiology of Plant-Phosphorous Interactions (eds. P.J. White and J.P. Hammond): 31-49. Springer.

Thomas, G.N., 2001. Late Middle Pleistocene pollen biostratigraphy in Britain: pitfalls and possibilities in the separation of interglacial sequences. Quaternary Science Reviews, 20: 1621-1630.

Tobolski, K., 2000. Przewodnik do oznaczania torów i osadów jeziornych (in Polish). Vademecum Geobotanicum 2, Wydawnictwo Naukowe PWN, Warszawa.

Tzedakis, P.C., 2010. The MIS 11-MIS 1 analogy, southern European vegetation, atmospheric methane and the "early anthropogenic hypothesis". Climate of the Past, 6: 131-144.
Tzedakis, P.C., Wolff, E.W., Skinner, L.C., Brovkin, V., Hodell, D.A., McManus, J.F., Raynaud, D., 2009. Can we predict the duration of an interglacial? Climate of the Past, 8: 1473-1485.

Velichkevich, F.Yu., Zastawniak, E., 2006. Atlas of the Pleistocene vascular plant macrofossils of Central and Eastern Europe, Part 1 - Pteridophytes and monocotyledons. W. Szafer Institute of Botany, Polish Academy of Sciences, Kraków.

Velichkevich, F.Yu., Zastawniak, E., 2008. Atlas of the Pleistocene vascular plant macrofossils of Central and Eastern Europe. Part 2 - Herbaceous dicotyledons. W. Szafer Institute of Botany, Polish Academy of Sciences, Kraków.

West, R.G., 1962. A note on Taxus pollen in the Hoxnian Interglacial. New Phytologist, 61: 189-190.

Zagwijn, W.H., 1996. The Cromerian Complex Stage of the Netherlands and correlation with other areas in Europe. In: The Early Middle Pleistocene in Europe (ed. Ch. Turner): 145-172. Balkema, Rotterdam.

Żarski, M., Nita, M., Winter, H., 2005. New interglacial sites in the region of the Wilga and Okrzejka river valleys at the Żelechów Upland (SE Poland) (in Polish with English summary). Przegląd Geologiczny, 52: 137-144. 